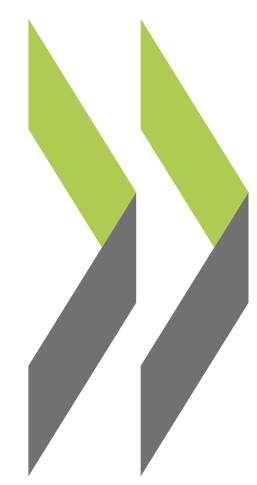

OECD Science, Technology and Industry Working Papers 2019/08

\section{Global value chains} and the shipbuilding industry
Karin Gourdon, Christian Steidl 


\section{OECD Science, Technology and Industry Working Papers}

OECD Working Papers should not be reported as representing the official views of the OECD or of its member countries. The opinions expressed and arguments employed are those of the authors.

Working Papers describe preliminary results or research in progress by the author(s) and are published to stimulate discussion on a broad range of issues on which the OECD works. Comments on Working Papers are welcomed, and may be sent to Directorate for Science, Technology and Innovation, OECD, 2 rue André-Pascal, 75775 Paris Cedex 16, France.

This document, as well as any data and any map included herein, are without prejudice to the status of or sovereignty over any territory, to the delimitation of international frontiers and boundaries and to the name of any territory, city or area.

(C) OECD 2019

You can copy, download or print OECD content for your own use, and you can include excerpts from OECD publications, databases and multimedia products in your own documents, presentations, blogs, websites and teaching materials, provided that suitable acknowledgment of OECD as source and copyright owner is given. All requests for commercial use and translation rights should be submitted to rights@oecd.org. 


\section{Acknowledgments}

The authors are grateful to Ali Alsamawi, Joaquim J. M. Guilhoto and Norihiko Yamano from the OECD Directorate for Science, Technology and Innovation (OECD/STI) for the preparation and update of the OECD Trade in Value Added (TiVA) database to the level of the shipbuilding industry. For more information on the database visit: http://oe.cd/tiva.

The authors are also thankful to Sarah Box, Laurent Daniel, Nick Johnstone and Dirk Pilat (OECD) for their comments and constructive feedback. Javier Lopez Gonzalez, Yuki Matsumoto and Sébastien Miroudot (OECD) also provided valuable comments.

A previous version of this document presented and discussed by the OECD Council Working Party on Shipbuilding (WP6) is also available on O.N.E under the reference code: C/WP6(2018)15. 
GLOBAL VALUE CHAINS AND THE SHIPBUILDING INDUSTRY

Karin Gourdon ${ }^{1}$ and Christian Steidl

\section{Abstract}

This paper provides an initial assessment of the shipbuilding industry in the context of global value chains by presenting new descriptive evidence on value added generation and sourcing patterns of intermediate inputs for ship construction of major shipbuilding economies. The findings reveal that shipbuilding relies heavily on intermediate inputs as around $70-80 \%$ of the final output value of ship production is generated through supplier sectors. Concerning sourcing activity, China appears to be the most self-sufficient among the four jurisdictions studied, followed by Japan and the EU28, while Korea seems to be more globally integrated. The analysis also explores variations among the four economies in the cost structure of shipbuilding inputs, which might partly be explained by differences in the ship types produced.

Keywords: global value chains, input output tables, shipbuilding, value added

JEL Classification: F14, L23, L62

\footnotetext{
${ }^{1}$ Karin.Gourdon@,oecd.org
} 


\section{Table of contents}

GLOBAL VALUE CHAINS AND THE SHIPBUILDING INDUSTRY ...................................... 4

Executive Summary ...................................................................................................................................... 6

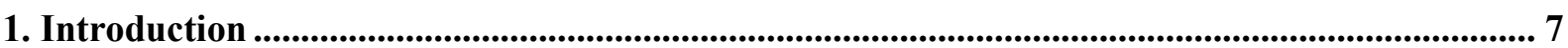

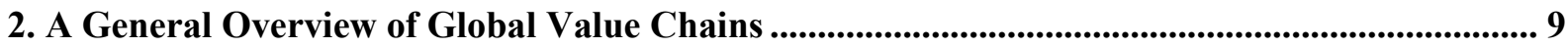

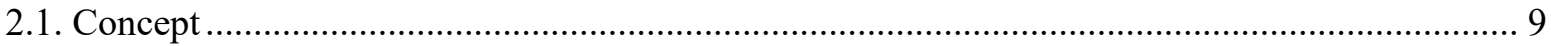

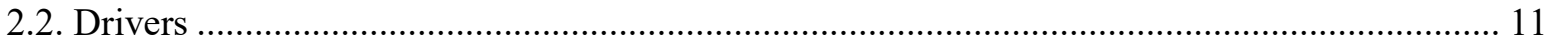

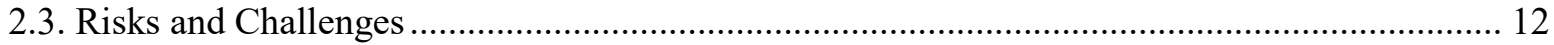

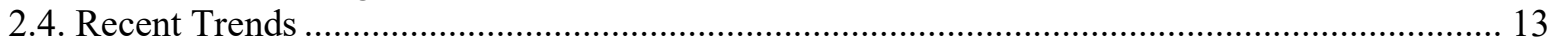

3. Global Value Chains and the Shipbuilding Industry .......................................................................... 14

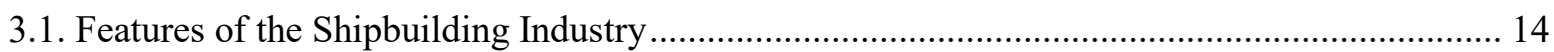

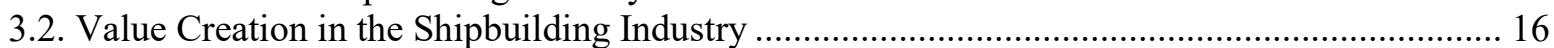

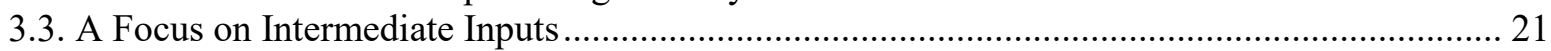

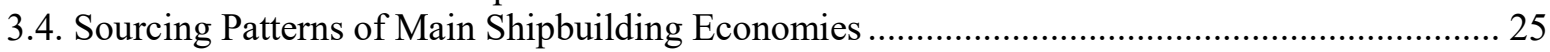

4. Concluding Remarks................................................................................................................................ 28

Annex A. Description of Industry Classification of Shipbuilding................................................... 29

References …...................................................................................................................................................... 32

Figures

Figure 1. A simplified representation of a global value chain............................................................. 9

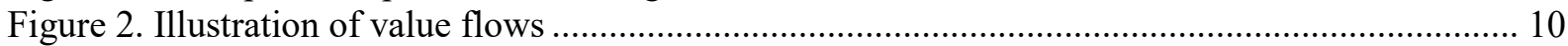

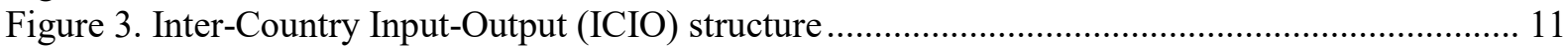

Figure 4. General steps of a shipbuilding production process............................................................ 15

Figure 5. Overview of main industries involved in the shipbuilding value chain ................................. 16

Figure 6. Ratio of shipbuilding value added to final output .............................................................. 17

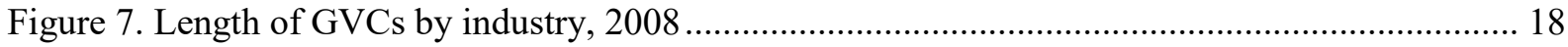

Figure 8. Sources of value added in ship manufacturing ................................................................... 19

Figure 9. Domestic value added as share of global value added, shipbuilding industry ....................... 20

Figure 10. Domestic output as share of global output value, shipbuilding industry ............................ 21

Figure 11. Disaggregation of total output into value added and costs of intermediate inputs for 201522

Figure 12. Cost shares of materials and equipment/systems by ship types ........................................ 24

Figure 13. Domestically sourced share of five major intermediate inputs ......................................... 25

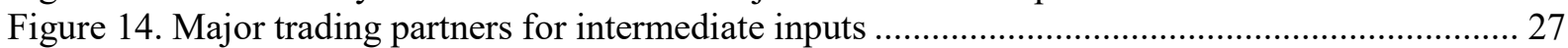

Boxes

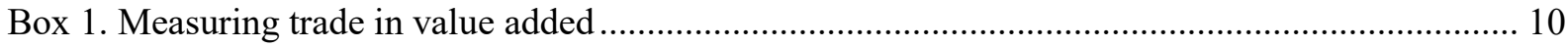

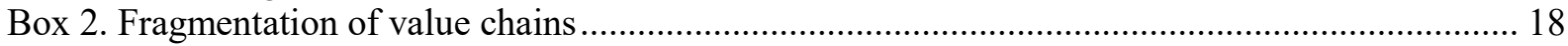




\section{Executive Summary}

Production networks are becoming increasingly global. Decreasing transportation costs as well as advances in information and communication technology (ICT) have helped facilitate the creation and notable expansion of global value chains (GVCs). This international fragmentation of production stages is a powerful driver of efficiency and firm competitiveness, and can partly explain product mix differences across countries.

The present report contributes to the literature on global value chains by providing a preliminary analysis of international production networks in the shipbuilding industry using Inter-Country Input-Output (ICIO) data. The work draws on a break-down of the latest update of the OECD ICIO database and the Trade in Value Added (TiVA) indicators to the level of the shipbuilding industry. This allows a comparison of value creation and bilateral trade flows across economies and time, and provides descriptive evidence about differences in sourcing patterns.

The study's results reveal the following stylised facts:

- Shipbuilding, as an assembly industry, relies heavily on intermediate inputs, similar to the automotive industry. In major shipbuilding economies, direct value added accounts for between $20 \%$ and $30 \%$ of shipbuilding output value. In turn 70 $80 \%$, the lion's share of the value of output, comes from intermediate inputs.

- With increasingly globalised production networks, not all of this value generation takes place domestically. While the People's Republic of China (hereafter "China"), Japan and the European Union (EU28) each had a domestic value added share of over $80 \%$ in 2015 , the same measure, as expected for smaller economies, was lower in Korea with 65\%.

- The top five supplier industries to shipbuilding are iron and steel, shipbuilding (i.e. intra-industry transactions), wholesale trade, machinery and equipment, as well as fabricated metal products. The differences in cost shares across economies may partly be a result of variations in the product mix of ship yards.

- An analysis of differences in sourcing patterns reveals that China is rather selfsufficient and inward-focused, followed by Japan and the EU28. Korea, in contrast, seems to be more globally integrated and participates more strongly as a user of foreign intermediate inputs.

This work provides an overview of the position of different economies' shipbuilding industries in global value chains and their sourcing patterns, with a view to help policy makers assess differences in their industry's production activity. 


\section{Introduction}

In the past, almost the entire production process usually took place in one country. This organisation of production has become more complex nowadays, as sourcing networks increasingly internationalised and supply chains span over multiple economies. Rather than being manufactured and assembled in a single country, products today are "made in the world", adding value to the end-product at each step of the process (OECD, 2013 $\left.{ }_{[1]}\right)$.

In the last few decades, developments in information and communication technologies have substantially contributed to the creation and expansion of such international production networks, i.e. global value chains (GVCs). The increasing efficiency in information sharing, communication and transportation of goods made it possible for firms to collaborate over long distances throughout the supply chain. ${ }^{1}$ These technological improvements, together with trade policy reforms (e.g. reduction in trade tariffs) as well as the incentive to access resources and markets, advanced the integration and acceleration of economic activity across national borders and connect firms, workers and consumers around the world (Sturgeon, 2013 $3_{[2]}$; OECD, 2013 $[1]$ ).

Due to the participation of many firms and countries throughout the production process, these international networks can result in rather complex supply-chain structures. In view of such intricate cross-border networks, it is informative to analyse the domestic and foreign value added, i.e. contributions of domestic and foreign production to the final product value (Elms and Low, 2013 $3_{[3]}$ ), moving beyond using traditional trade statistics alone. Two indicators of GVC participation are commonly distinguished: Exporting firms taking part in global value chains as users of foreign inputs (backward linkage) or as suppliers of intermediate goods and services which are subsequently used in other countries' exports (forward linkage). Inter-Country Input-Output (ICIO) tables enable researchers to undertake detailed analyses of each country's contribution to a product's (final) value through these and other indicators. Research in this area has extensively used such information to analyse the effect of GVCs on a country's development (see for instance OECD (2013 $\left.{ }_{[1]}\right)$; World Bank $\left.\left(2017_{[4]}\right)\right)$.

Latest research on the industry- and firm-level depicts these global value chains as a powerful driver of productivity growth and competitiveness, job creation, and living standards. Ways in which companies can enhance their productivity include the possibility to specialise in core tasks (by outsourcing ancillary tasks), to access cheaper inputs and to benefit from spill-over effects from foreign firms (Criscuolo and Timmis, 2017 ${ }_{[5]}$ ). Recently, Constantinescu, Mattoo and Ruta $\left(2017_{[6]}\right)$ found in an industry-level crosscountry analysis that "an increase by 10 percent in the level of GVC participation increased average [labour] productivity by 1.7 percent". Furthermore, the results by Kummritz $\left(2016_{[7]}\right)$ suggest that an increase by $1 \%$ in GVC participation through forward linkages "leads $[\ldots]$ to $0.33 \%$ higher labour productivity". ${ }^{2}$

An OECD study $\left(2015_{[8]}\right)$ on the impact of GVCs on job creation ${ }^{3}$ shows that for the industry category "other transport equipment" (which includes shipbuilding) jobs embodied in gross exports amount to around $125 \%$ of that domestic industry's employment. ${ }^{4}$ This value implies that, due to additional employment effects in upstream sectors, more jobs are supported by exports than total employment in the "other transport equipment" industry itself. This result thus shows that total jobs sustained by an industry extend far beyond just its direct employment. 
Despite the documented benefits of GVCs, the growing dependence on global production networks also bears risks: Situations where disruptions in one part of the supply chain have substantial consequences in subsequent production steps are not uncommon (Elms and Low, 2013 $[3]) .{ }^{5}$ Well-functioning supply chains are thus undoubtedly a necessary precondition for firms to be successful. From an employment perspective, further risks include loss of domestic employment for certain job and skill categories due to trends in production offshoring, ${ }^{6}$ and downward pressure on wages ${ }^{7}$, although the overall employment effect of GVC participation has been shown to be positive (OECD, $\left.2013_{[1]}\right)$.

While trade and GVCs can generate economic welfare, as illustrated above, the full range of these employment and growth benefits can only materialise when complementary policies are implemented (OECD, $2015_{[8]}$ ). For example, policy settings need to enable and facilitate adjustments in the economy, resulting from outsourcing and offshoring activities, "through labour market and social policies and through investment in education and skills" (OECD, 2013 [1]).

The following analysis aims to provide a better understanding of GVCs in general and of value chains in the shipbuilding industry in particular, with a focus on major shipbuilding economies. The work draws on the results obtained from the OECD Inter-Country InputOutput (ICIO) database and the Trade in Value Added (TiVA) indicators.

The study reveals several interesting results. Shipbuilding as an assembly industry relies heavily on intermediate inputs, similar to the automotive industry. In major shipbuilding economies, between $20 \%$ and $30 \%$ of value added ${ }^{8}$ as share of final output is generated in the shipbuilding industry itself. Hence, with $70-80 \%$ the lion's share of the final output value of ship production is generated through supplier sectors. ${ }^{9}$ In light of increasingly globalised production networks, not all of this value generation takes place domestically. While China, the EU28 and Japan each had a domestic value added share of over $80 \%$ in 2015 , the same measure, as expected for smaller economies, was lower in Korea with $65 \%$.

The top five supplier industries to shipbuilding are iron and steel, shipbuilding (i.e. intraindustry transactions), wholesale trade, machinery and equipment as well as fabricated metal products. The differences in cost shares across countries may partly be a result of variations in the product mix of ship yards and the disparities in input cost shares across these ship types. For instance, while bulkers, containerships and oil tankers require comparatively more steel components and propulsion \& power generation parts as inputs, LNG and offshore vessels need more cargo handling equipment (Brun and Frederick, $2017_{[9]}$ ).

An analysis of differences in sourcing patterns reveals that China sources more than $90 \%$ of the value of the top five intermediate inputs for ship production domestically. Similarly, Japan and the EU28 also appear to be comparatively inward focused regarding its major inputs. Finally, Korea seems to be more globally integrated and participates more strongly as a user of foreign intermediate inputs.

The remainder of this paper is structured as follows: Section 1 provides a general explanation of GVCs, drivers, challenges and recent trends. Section 2 presents the features of GVCs in the shipbuilding industry followed by an analysis of GVC indicators for a selection of major shipbuilding economies. The final section concludes on the results and provides further remarks. 


\section{A General Overview of Global Value Chains ${ }^{10}$}

\subsection{Concept}

A value chain comprises all stages of production, from the initial design of the product to its end use. These tasks can be undertaken by one vertically integrated firm or by multiple firms, in which case each can be specialised in one single production step. In both instances, value (or supply) chains have become increasingly international, giving rise to the concept of "global value chains" 11 (OECD, 2013 $\left.{ }_{[1]}\right)$.

Figure 1 illustrates a global value chain in a simplified way. As the production of goods is often split into various steps and located in the country with a comparative advantage in this particular activity, the whole production process spans over several economies before a final product is assembled. In practice, this often means that inputs are sourced from various supplier countries, which in turn source from second tier suppliers in third countries, etc. (OECD, 2013 $\left.{ }_{[1]}\right)$.

Figure 1. A simplified representation of a global value chain

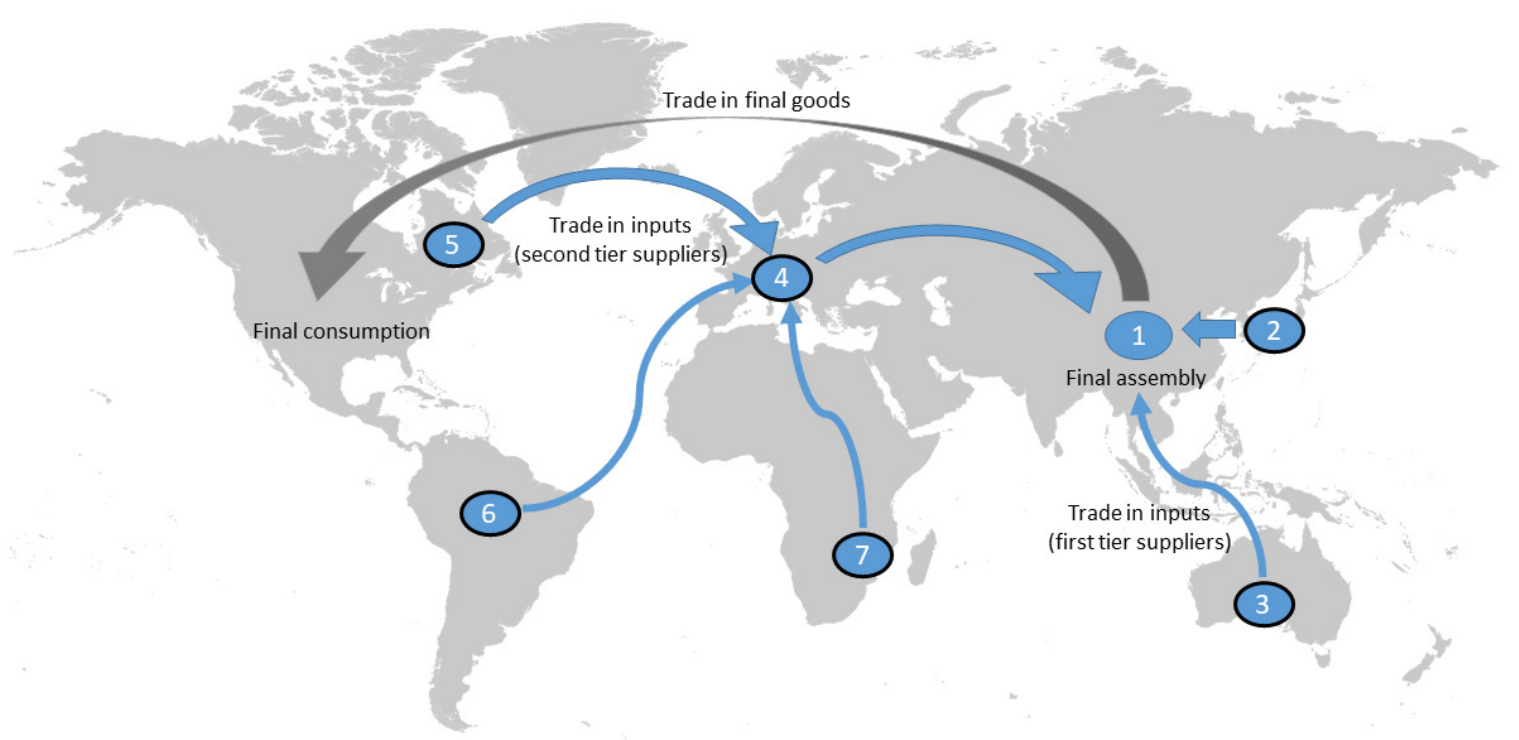

Note: 2, 3 and 4 represent intermediate products which are combined into 1 (i.e. the final product); 4 as an intermediate product itself is composed of inputs 5,6 and 7 .

Source: Authors' representation based on OECD (2013[1]).

Two indicators of GVC participation are commonly distinguished: Exporting firms taking part in global value chains as users of foreign inputs (backward linkage) or as suppliers of intermediate goods and services which are subsequently used in other countries' exports (forward linkage). ${ }^{12}$ These participations can become very complex and in-depth data is required to meaningfully analyse such production linkages. Compared to traditional trade data, Inter-Country Input-Output (ICIO) tables allow to better track each country's participation in GVCs. Box 1 describes the concept and the databases in more detail. 


\section{Box 1. Measuring trade in value added}

ICIO data helps to deal with double counting which occurs implicitly in current gross trade statistics. This data allows measuring the flows of value added by a country in the production of a good or service.

For instance, as depicted in Figure 2, country A exports USD 100 worth of goods, which were produced entirely in A, to country B, which further adds USD 10 to the product's value and then exports a product worth USD 110 to C. Traditional trade data shows total global exports and imports of USD 210 and would track a trade deficit of C with B of USD 110 and no trade at all between A and C. However, in fact only USD 110 of value added has been created. Traditional measures would thus neither reveal that $\mathrm{A}$ is the major beneficiary of C's consumption, which ultimately caused A's exports of USD 100 to B, nor that $\mathrm{B}$ benefits from only USD 10 in value added from C's consumption. (OECD, $\left.2013_{[1]}\right)$

Figure 2. Illustration of value flows

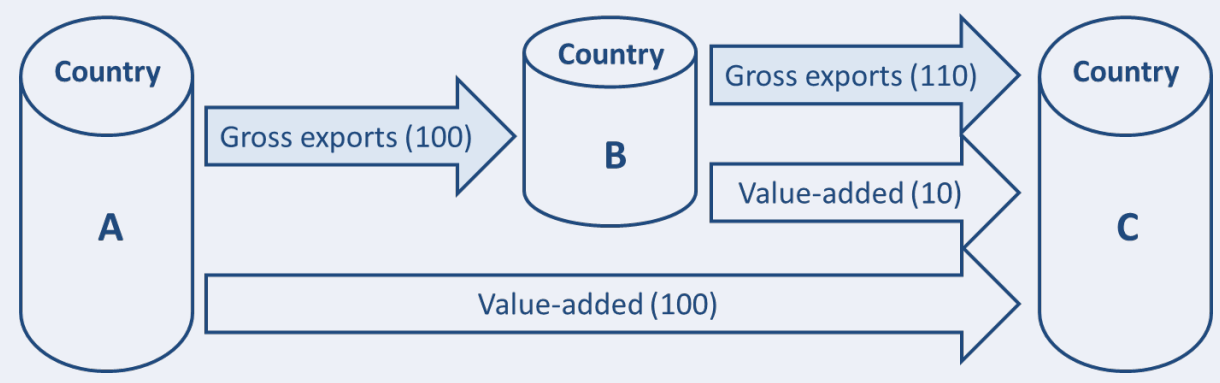

Source: Authors' representation based on OECD (2013[1]).

OECD indicators on Trade in Value Added are based on this idea elaborated above and are derived from an ICIO table (Figure 3). Its latest version was updated in 2018 and covers the years 2005 to 2015 . This ICIO table describes interactions between industries and consumers for 64 economies and 36 industries. Each cell of the table shows the value of a transaction, which is an output of the industry denoted in the row and an input for the industry in a specific country shown in the column. Additional columns to the right of the intermediate demand part of the table represent the use of outputs for final consumption (including capital formation and household) as well as consumption by non-residents. All those transactions can be domestic as well as international, which are shown in the diagonal and off-diagonal blocks respectively. Additional rows at the bottom indicate taxes and the value added creation by the corresponding industry. 
Figure 3. Inter-Country Input-Output (ICIO) structure

\begin{tabular}{|c|c|c|c|c|c|c|c|c|c|c|c|c|c|c|}
\hline \multirow{3}{*}{\multicolumn{2}{|c|}{$\begin{array}{l}\text { Inter-country I-O } \\
\text { at basic prices }\end{array}$}} & \multicolumn{6}{|c|}{ Intermediate demand } & \multicolumn{3}{|c|}{$\begin{array}{l}\text { Final consumption and } \\
\text { capital formation }\end{array}$} & \multicolumn{3}{|c|}{$\begin{array}{l}\text { Direct purchases } \\
\text { by non-residents }\end{array}$} & \multirow{3}{*}{ Output } \\
\hline & & \multicolumn{2}{|c|}{ Cou A } & \multicolumn{2}{|c|}{ Cou B } & \multicolumn{2}{|c|}{ Cou C } & \multirow{2}{*}{ Cou A } & \multirow{2}{*}{ Cou B } & \multirow{2}{*}{ Cou C } & \multirow{2}{*}{ Cou A } & \multirow{2}{*}{ Cou B } & \multirow{2}{*}{$3 \mathrm{Cou} C$} & \\
\hline & & Ind 1 & Ind 2 & Ind 1 & $\operatorname{lnd} 2$ & Ind 1 & Ind 2 & & & & & & & \\
\hline \multirow[t]{2}{*}{ Cou $A$} & Ind 1 & & & & & & & & & $\longrightarrow$ & & & & $\mathrm{X}(\mathrm{A} 1)$ \\
\hline & Ind $2=$ & $\rightarrow$ & & & & & & & & & & & & $X(\mathrm{~A} 2)$ \\
\hline \multirow{2}{*}{ Cou B } & Ind 1 & & & & & & & & & & & & & $\mathrm{X}(\mathrm{B} 1)$ \\
\hline & Ind 2 & $\rightarrow$ & & & & & & & & & & & & $\mathrm{X}(\mathrm{B} 2)$ \\
\hline \multirow{2}{*}{\multicolumn{2}{|c|}{$\begin{array}{|ll|}\text { Cou C } & \begin{array}{l}\text { Ind 1 } \\
\text { Ind 2 }\end{array} \\
\end{array}$}} & & & & & & & & & & & & & $\mathrm{X}(\mathrm{C} 1)$ \\
\hline & & & & & & & & & & & & & & $\mathrm{X}(\mathrm{C} 2)$ \\
\hline \multirow{2}{*}{\multicolumn{2}{|c|}{ Taxes less subsidies .. }} & \multicolumn{6}{|c|}{... on intermediate products } & \multicolumn{6}{|c|}{... on final products } & \\
\hline & & NTZA1 & NTZA2 & NTZB1 & NTZB2 & $\mathrm{NTZC1}$ & $\mathrm{NTZC2}$ & $\mathrm{FA}$ & $\mathrm{FB}$ & $\mathrm{FC}$ & FA & $\mathrm{FB}$ & $\mathrm{FC}$ & \\
\hline \multicolumn{2}{|c|}{ Value-added } & $\mathrm{V}(\mathrm{A} 1)$ & $\mathrm{V}(\mathrm{A} 2)$ & $V(B 1)$ & $\mathrm{V}(\mathrm{B} 2)$ & $V(C 1)$ & $\mathrm{V}(\mathrm{C} 2)$ & & & & & & & \\
\hline \multicolumn{2}{|l|}{ Output } & $X(A 1)$ & $X(A 2)$ & $\mathrm{X}(\mathrm{B} 1)$ & $\mathrm{X}(\mathrm{B} 2)$ & $X(C 1)$ & $\mathrm{X}(\mathrm{C} 2)$ & & & & & & & \\
\hline \multirow{2}{*}{\multicolumn{2}{|c|}{ Key: }} & \multicolumn{4}{|c|}{$\begin{array}{l}\text { Cross-border flows of intermediate } \\
\text { goods and services }\end{array}$} & & \multicolumn{4}{|c|}{$\begin{array}{l}\text { Cross-border flows of final goods and } \\
\text { services }\end{array}$} & & & & \\
\hline & & \multicolumn{4}{|c|}{$\begin{array}{l}\text { Domestic flows of interme diate goods } \\
\text { and services }\end{array}$} & & \multicolumn{4}{|c|}{$\begin{array}{l}\text { Domestic flows of final goods and } \\
\text { services }\end{array}$} & & & & \\
\hline
\end{tabular}

Source: Presentation by Mr Colin WEBB at the OECD Committee on Industry, Innovation and Entrepreneurship (CIIE) in April 2018.

Derived from the ICIO, the OECD Trade in Value Added database includes, among others, the following indicators: breakdowns of gross exports by industries into their domestic and foreign content (with the domestic content split into direct, indirect and re-imported components); the services content of gross exports by exporting industry (broken down by foreign/domestic origin); bilateral trade balance in value added terms; and intermediate imports embodied in exports, as a percentage of total intermediate imports. ${ }^{13}$

\subsection{Drivers}

When describing the rise of international production, two phases of that development can generally be distinguished. In what Baldwin $\left(2012_{[10]}\right)$ describes as the "first unbundling", trade costs fell substantially thanks to new railroads and steamships, tariff liberalisation and containerisation. At the same time, he argues that the complexity of the production process implied that tasks could not be split up among various countries due to the problem of coordinating those steps of production. Thus, the forces favouring agglomeration (e.g. scale economies) were stronger than the wage differential that would have favoured dispersion of production and the allocation of each task in the economy where its execution would be cheapest (Baldwin, 2012 $[10])$.

This changed with the rapid rise of Information and Communication Technology (ICT), which led to what Baldwin $\left(2012_{[10]}\right)$ calls the "second unbundling". As coordination became simpler, wage differentials between countries at different stages of development started to drive dispersion and production steps were allocated in the economies with the respective cost advantages (Baldwin, 2012[10]). Nowadays, economies of scale still play an important role, but rather at one stage of production (OECD, 2013 $\left.{ }_{[1]}\right)$. 
Firms that decide to no longer source (some of their) inputs domestically can offshore production and consequently import their intermediate inputs from abroad, either from their own factories located in another jurisdiction or from a foreign supplier. In the former case, the production of a certain (input) good (or a certain stage of production) is located in another country through foreign direct investment (FDI). Various factors can inform this decision, for instance cost considerations (e.g. lower wages, tax incentives), better access to upstream inputs (including raw materials) or to specialised local human capital. While the product is still made by the same company, different stages of production are divided internationally and are thus contributing to the international trade in intermediate products. Alternatively, a company may also decide to source inputs from a foreign supplier, which equally increases trade in intermediates. These sourcing activities oftentimes result in "access to cheaper, more differentiated and better quality inputs" and can enhance firms' export competitiveness (OECD, $\left.2013_{[1]}\right)$.

\subsection{Risks and Challenges}

Despite the advantages that led to the spread of global value chains, there are also several risks and challenges associated with this form of production. Many companies have adopted lean structures such as just-in-time deliveries to reduce inventory costs. This, however, makes them more vulnerable to disruptions in their supply chain. If the disruption affects a critical input that is sourced without having an alternative supplier, production could break down and consequently also affect downstream industries. As firms might not necessarily have an overview of their complete supply chain, they might also be exposed to risks they are not immediately aware of (OECD, 2013 $\left.{ }_{[1]}\right)$.

An example of the repercussions of disruptions in the GVC system are the consequences experienced by many industries in the aftermath of the earthquake and tsunami in Japan in 2011. Because of the immediate damage after the disaster, some Japanese factories had to slow down production or close plants entirely. As Japan is a crucial supplier of higher value intermediate goods, these disruptions were felt by many downstream companies such as automotives (OECD, 2013 ${ }_{[1]}$; Gereffi and Luo, 2014 $\left.{ }_{[11]}\right)$.

Another challenge that studies have revealed is an uneven distribution between jurisdictions with regards to the value added created along a value chain, with lower value added creation in assembly than in upstream industries (such as R\&D) or downstream industries (such as marketing). The graphical representation of this phenomenon has been coined the "smiling curve" by Acer's founder Stan Shih to describe the characteristics of the IT industry (OECD, 2013 $\left.{ }_{[1]}\right)$. As will be outlined in more detail in a later section, shipbuilding, which in principle is an assembly industry, is located rather at the lower end of a spectrum of value creation in most economies. The perceived problem that the assembly industry itself tends to be a segment of rather low value added has led many governments to pursue policies addressing the challenge to "move up the value chain" in order to capture more of the value creation within the production process, partly by resorting to local content requirements (LCRs). From a social standpoint, however, it should be noted that employment is likely to be the inverse of the "smiling curve", as manufacturing tends to provide more, albeit often lower paid, jobs than up- or downstream industries (Lopez Gonzalez, 2016 $6_{[12]}$ ). It has furthermore been argued that the domestic share of value added might be less important than the total amount of domestic value creation (ibid.). 


\subsection{Recent Trends}

While GVC integration has increased steadily until 2008, estimations indicate that the expansion of GVCs might have levelled off since 2011 (ECB, 2016 $[13]$; OECD, 2018 $\left.{ }_{[14]}\right){ }^{14}$ Several reasons may have led to this development. Regulatory measures such as LCRs, for instance, might encourage multinational companies to locate production within their export economy. Two thirds of respondents to a survey conducted by the European Central Bank (ECB), for instance, name LCRs as one main reason for relocation of production outside the European Economic Area and to their export markets, leading to local sourcing patterns that may substitute previous trade flows $\left(\mathrm{ECB}, 2016_{[13]}\right)$. Other studies similarly argue that with manufacturers relocating to the market of final demand, supply industries might eventually follow, curbing trade in intermediates (McKinsey, 2014 $[15]$ ). Recent OECD work furthermore underscores that automation and robotics might decrease the tendency for offshoring and thus could be slowing the rate of GVC expansion (De Backer et al., $\left.2018_{[16]}\right) .{ }^{15}$ Moreover, in order to improve risk management and reduce the vulnerability to disruptions in their supply chains outlined above, some companies reportedly shorten their supply chains and/or engage in re-shoring. This also has the positive side-effect that it allows for more flexibility in view of changing demand patterns (OECD, $\left.2013_{[1]}\right)$. 


\section{Global Value Chains and the Shipbuilding Industry}

\subsection{Features of the Shipbuilding Industry}

Recent decades have witnessed an increasing concentration of shipbuilding in China, Korea and Japan, which together deliver more than $80 \%$ of ships in terms of compensated gross tons (CGT) ${ }^{16}$ While these three economies dominate the market for bulkers, tankers and containerships, cruise ships are mainly built at European yards.

Despite the differences among economies regarding the types of ships produced, the shipbuilding process itself remains nevertheless similar in the sense that it is a complex task which necessitates considerable coordination skills: workers need to assemble thousands of different components which have to be correctly manufactured and arrive just in time at the right place. For example, ships are assembled from up to 550000 parts for a complex research vessel or 900000 parts for cruise ships (SEA Europe, $2017_{[17]}$ ). ${ }^{17}$ Shipyards thus need to possess effective systems as well as management and organisational skills in order to generate information, develop production plans, control materials and achieve high quality standards in the production of components.

Figure 4 illustrates the general steps of the shipbuilding process. In reality, each ship yard organises its production differently that may also vary according to the ship type produced ${ }^{18}$ and decides on which stage to outsource. This description, which is taken from Stopford $\left(2003_{[18]}\right)$, therefore aims to provide a general overview of the process and a mention of upstream industries involved in the value generation process. Every ship production starts with a design period during which the yard works closely together with the customer to elaborate the ship design. At this stage, long lead-time items, such as steel and main engines, are ordered to arrive on time for the outfitting phase. Once the ordered steel has arrived, workers weld several steel parts and usually assemble the components into building blocks, which are subsequently used for ship construction. After that, the hull is outfitted with thousands of different items. As the painting stage was found to create bottlenecks when it was carried out at a late stage of production it is nowadays usually done throughout the production stages. The prefabricated items are lifted into the assembly dock where they are aligned and welded. Once the hull is completed, the dock is flooded and the ship is brought to an outfit quay. Finally, systems are commissioned to ensure the correct functioning of on-board systems, and main engine trials are conducted (Stopford, $2003_{[18]}$ ). 
Figure 4. General steps of a shipbuilding production process

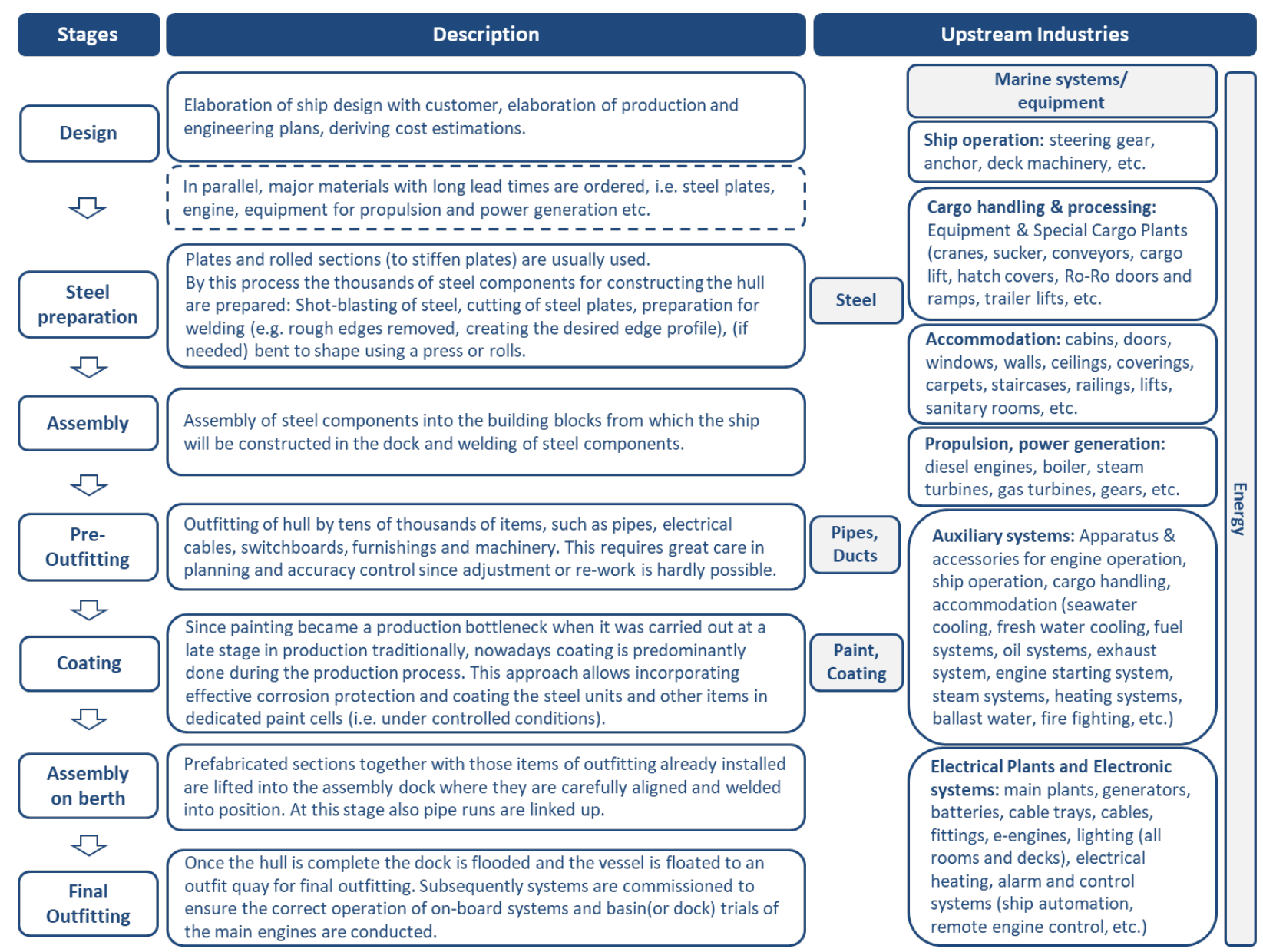

Source: OECD based on Stopford $\left(2003_{[18]}\right)$; Brodda $\left(2014_{[19]}\right)$

There are various industries involved in the production process. Figure 5 provides an overview of the main industries with steel and metals, and machinery products as major suppliers as well as maritime transport, offshore oil \& gas, and ship recycling etc. as endusers. In the next section we will analyse to what extent a country's shipbuilding industry is involved in GVCs through backward linkages. At the final stage, households and governments purchasing goods and services "consume" ships through the indirect usage of maritime transportation services. 
Figure 5. Overview of main industries involved in the shipbuilding value chain

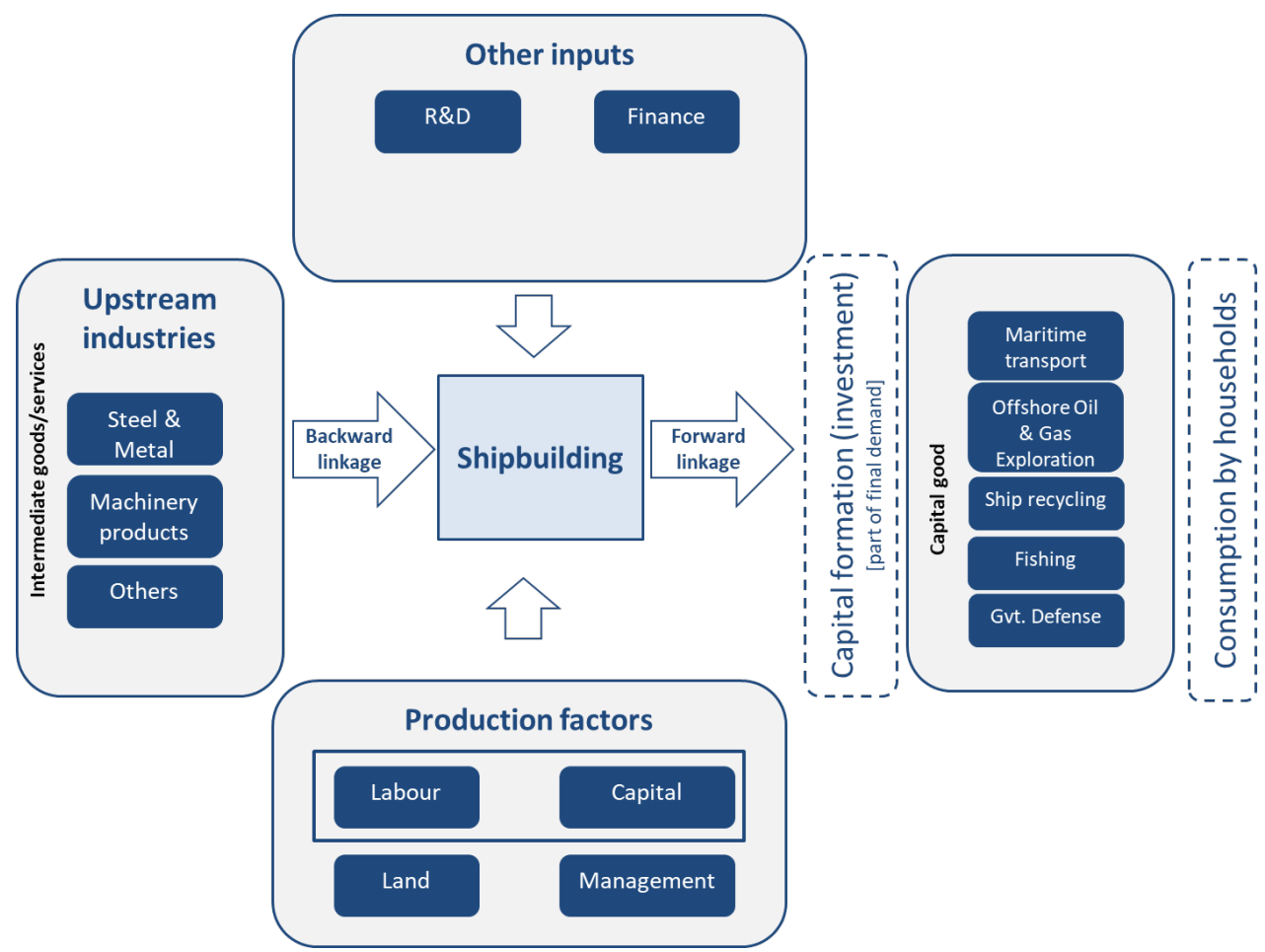

Source: Authors' representation.

\subsection{Value Creation in the Shipbuilding Industry}

This section provides preliminary insights into the interconnectedness of the shipbuilding industry in global value chains. The rich dataset of "Trade in Value Added" (TiVA) developed by the OECD allows for an analysis of sectoral value added generation and international sourcing patterns across time and economies. In order to analyse the shipbuilding industry specifically, a more detailed version of TiVA comprising 75 industries has been used for this report (OECD, 2018 ${ }_{[20]}$ ). Annex A provides an overview of the items included in the shipbuilding industry classification.

Before proceeding to the analysis, however, a few caveats about the data and its interpretation in connection with the shipbuilding industry need to be highlighted. As TiVA data is in current prices, differences over time might come from price developments, for instance changing costs for inputs, which in turn may affect some of the reported percentages. Furthermore, economies are specialised in the production of different ship types, giving rise to discrepancies in sourcing behaviour and making results across economies less comparable. The analysed category of shipbuilding also includes the manufacturing of warships, which is likely to alter the results for those jurisdictions where naval shipbuilding is more prevalent. Moreover, the precision of the data depends on the level of aggregation. More disaggregated results tend to entail a larger margin of error. Some of these caveats will also be highlighted at the respective steps of the analysis. Finally, yet importantly, the analysis in this paper has been based on a preliminary version of the TiVA 2018 update. Future studies using the final database might thus come to slightly different results. 
Given the high share that inputs represent in the manufacturing process, shipbuilding can be qualified as an assembly industry. The contribution to the final value of the ship can thus be meaningfully separated into intermediate inputs and shipbuilding assembly. In the main shipbuilding economies, between $20 \%$ and $30 \%$ of the value of the final product is created in the shipbuilding industry itself, while intermediate inputs account for the rest. In other words, the lion's share of the final output value of ship production $(70-80 \%)$ is generated through supplier sectors. ${ }^{19}$

To put the ratios of the shipbuilding industry into perspective, similar ratios are reported for the category "Motor vehicles, trailers and semi-trailers" $(\sim 25 \%)$. The lowest value added as share of final output in manufacturing in 2015 was recorded in the industry classification "Coke and refined petroleum products" $(\sim 20 \%)$, while one of the highest shares was associated with pharmaceutical products $(\sim 45 \%)$. The shipbuilding industry itself is thus situated rather at the lower end of value creation in most economies, which might be due to the fact that it is an assembly-intensive industry. Box 2 illustrates another perspective of the fragmentation of value chains across industries.

Figure 6 illustrates the value added contribution of the final ship assembly as share of final shipbuilding output by economy. For the majority of economies in 2015 the ratio amounts to around 20\%, while China, Japan and Norway are located rather at the higher end of the spectrum. With the exceptions of France and China, the ratio decreased from 2005 to 2015 for all economies depicted in the figure.

The results for the United States (hereafter "USA") require further explanation. The country stands out with one of the highest shares of value added over output with $48 \%$ in 2015. This may partly result from the abovementioned data constraint, as the product category used in this analysis also includes military shipbuilding, which plays a significant role in the USA, accounting for $60 \%$ of revenue in the shipbuilding industry in 2012 (IBIS World [2012], as cited in United States Maritime Administration (2013 $[21])$ ). ${ }^{20}$ Another noteworthy idiosyncrasy of the USA is the Jones Act - a local content requirement in place since 1920 that obliges local shipbuilding firms to source domestically the majority of input factors for the construction of Jones Act compliant vessels. ${ }^{21}$

Figure 6. Ratio of shipbuilding value added to final output

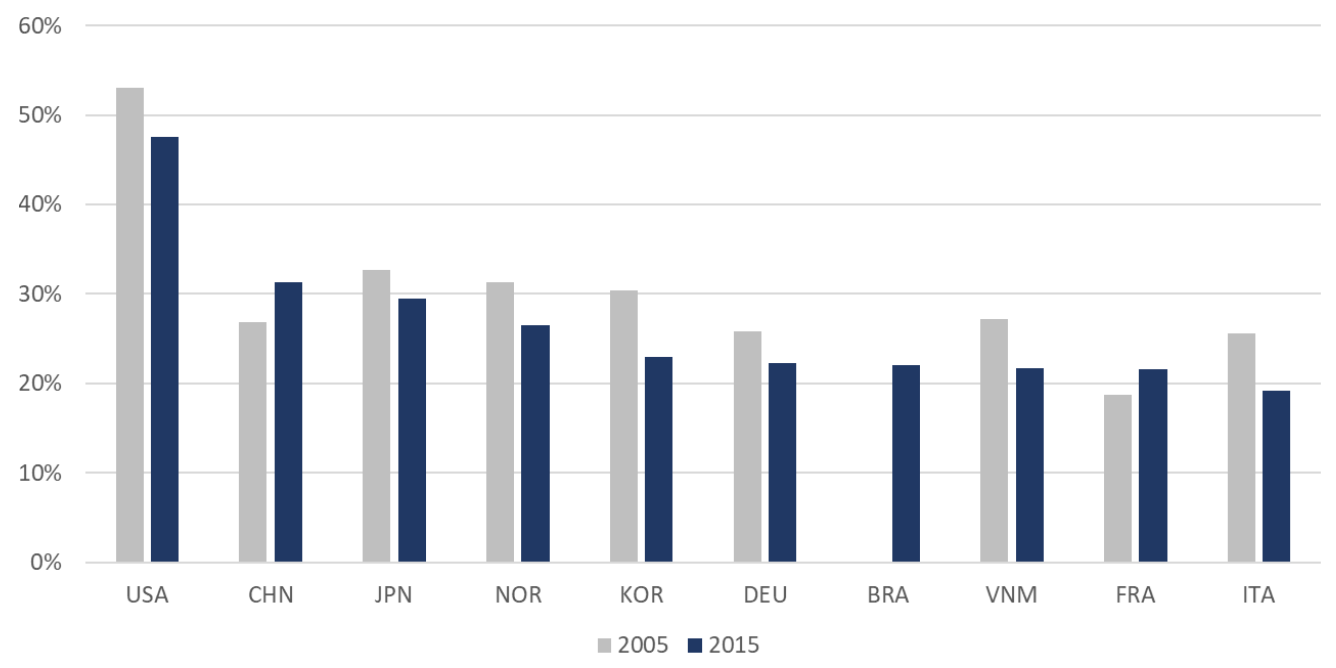

Note: Results for Brazil are omitted for the year 2005 because of data limitations.

Source: OECD Trade in Value Added (2018). 


\section{Box 2. Fragmentation of value chains}

Figure 7 shows a fragmentation index for a selection of industries that illustrates to what extent some sectors involve more supplier industries for the production of a good or service than others. The five industries with the highest number of intermediate industries involved in the production (i.e. most fragmented industries) are "TV and communication equipment", "motor vehicles", "basic metals", "textiles, leather and footwear" and "electrical machinery", while service industries tend to be less fragmented (De Backer and Miroudot, 2013 $3_{[22]}$ ). The shipbuilding industry is part of the category "other transport equipment" and located at the higher end of the spectrum. Although these results are based on data from 2008 they are still relevant today and useful for an illustration of fragmentation aspects across sectors.

Figure 7. Length of GVCs by industry, 2008

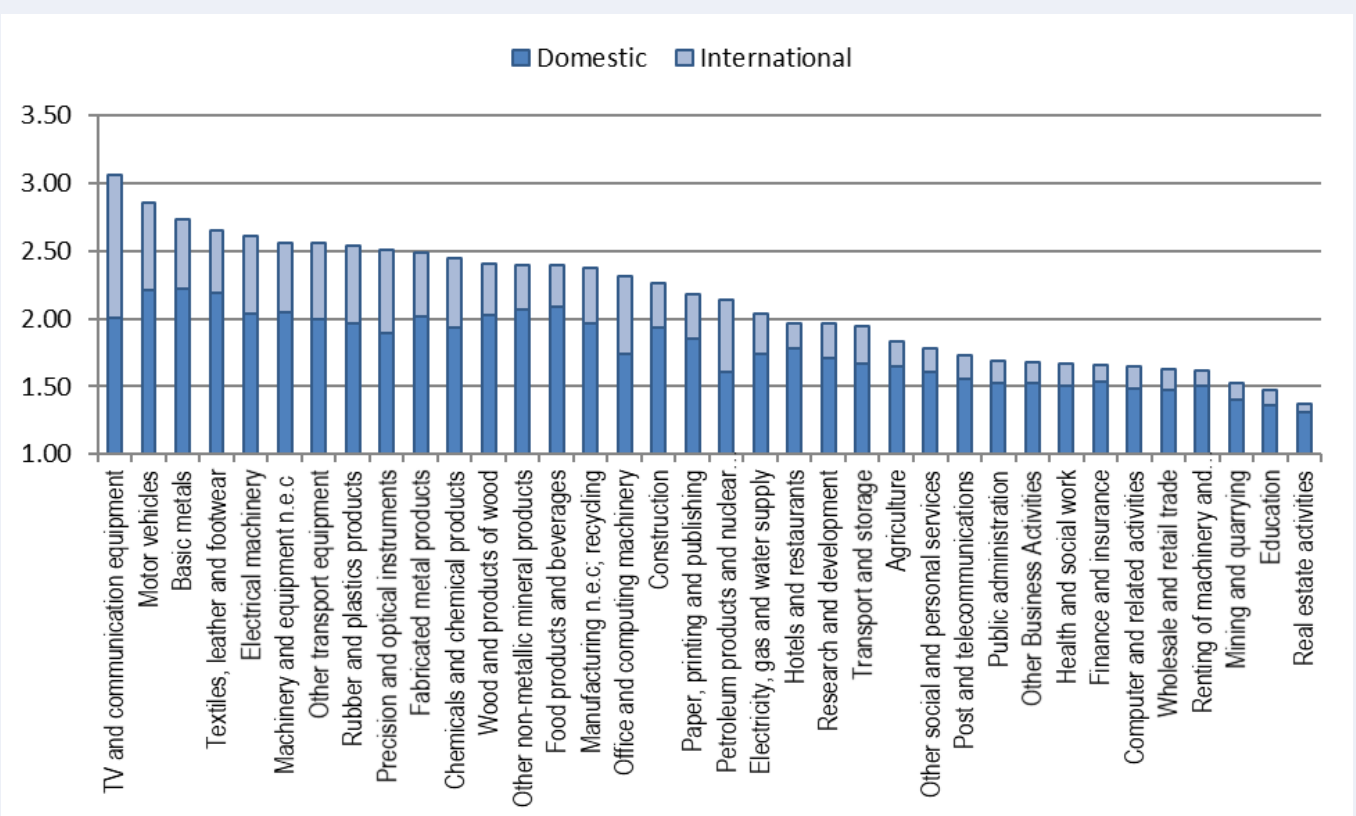

Note: The minimum value of the index is 1 when no intermediate inputs are used to produce a final good or service.

Source: De Backer and Miroudot (2013[22]).

While the analysis above has focused mainly on the value contribution of ship production, the inclusion of upstream industries can give interesting insights into how much of total value added can actually be attributed to the economy where the ship is assembled. While changes over time could to some extent result from technological changes, they might nevertheless give some indication about the general developments in the industry.

For this exercise, Figure 8 provides an overview of the domestic and foreign shares of value added in ship production across economies for 2005 and 2015. In contrast to Figure 6, inputs are now decomposed into their value added components, and percentages are expressed in terms of total value added in the whole value chain of ship manufacturing. The domestic value added content is disaggregated into one part related to the domestic 
shipbuilding industry (direct) and another part attributable to other domestic upstream sectors (indirect).

The results show that China, the EU28 and Japan all have a domestic value added share of over $80 \%{ }^{22}$ The same measure is markedly lower for Korea with $65 \%$. This difference could be explained by the fact that smaller economies tend to have higher foreign value added shares of exports (Kowalski et al., 2015 ${ }_{[23]}$ ). Analyses regarding sourcing patterns from domestic compared to foreign suppliers, which will be presented in Section 3.4, try to further investigate these discrepancies.

While most of the economies record a decline of their domestic value added shares between 2005 and 2015, China increased its share. This development might be driven by China's policy developments in the context of its $11^{\text {th }}$ Five Year Plan which was launched in 2006. The programme explicitly recognised the importance of the shipbuilding industry with an aim to improve domestic supply (Tsai, 2011 [24]). Increasing domestic content in shipbuilding still remains an important goal of China today, as "maritime equipment and high-tech ships" are key technologies outlined in the "Made in China 2025" strategic plan (MERICS, 2016[25]).

Treating intra-EU trade as domestic, the EU28 domestic share of value added accounts for $84 \%$ of total value creation in the shipbuilding industry in 2015 and is thus just as high as the corresponding value for Japan. This share has not changed significantly since 2005, when it stood at $86 \%$ (Figure 8$).{ }^{23}$

Figure 8. Sources of value added in ship manufacturing

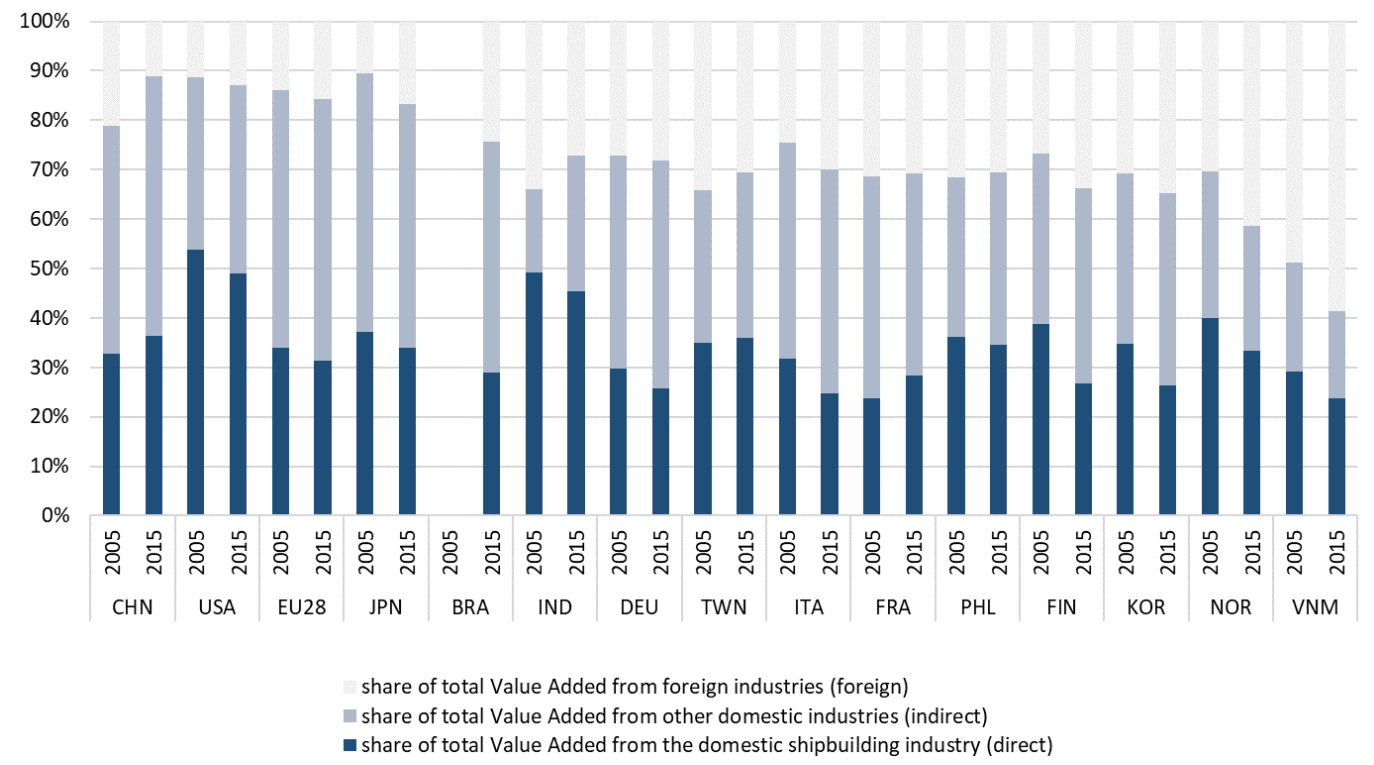

Note: Economies are sorted left to right according to their share of domestic value added contribution to total value added in 2015. Results for Brazil are omitted for the year 2005 because of data limitations.

Source: OECD Trade in Value Added (2018).

While these results focus primarily on the level of one economy, it is also informative to discuss these figures in a global context. Total value added creation in the shipbuilding industry itself increased from around USD 65 billion in 2005 to 108 billion in 2015, which coincided with an almost twofold increase of output values from USD 192 billion in 2005 
to USD 346 billion (in terms of deliveries an increase is recorded from 29 million CGT to 39 million CGT during the same period ${ }^{24}$ ). An analysis of value added in the global shipbuilding industry in different years suggests that the shares of economies' value added for Japan and EU28 have declined while it has more than doubled in China (Figure 9). At the same time, China also increased its share of global shipbuilding output value from $12 \%$ to almost one quarter (Figure 10), which corresponds to an increase in terms of CGT from $16 \%$ to $35 \%$. Thus, China accounts for more value creation primarily by virtue of production increase, which is fuelled through the growth of its heavy manufacturing industries..$^{25}$

Figure 9. Domestic value added as share of global value added, shipbuilding industry

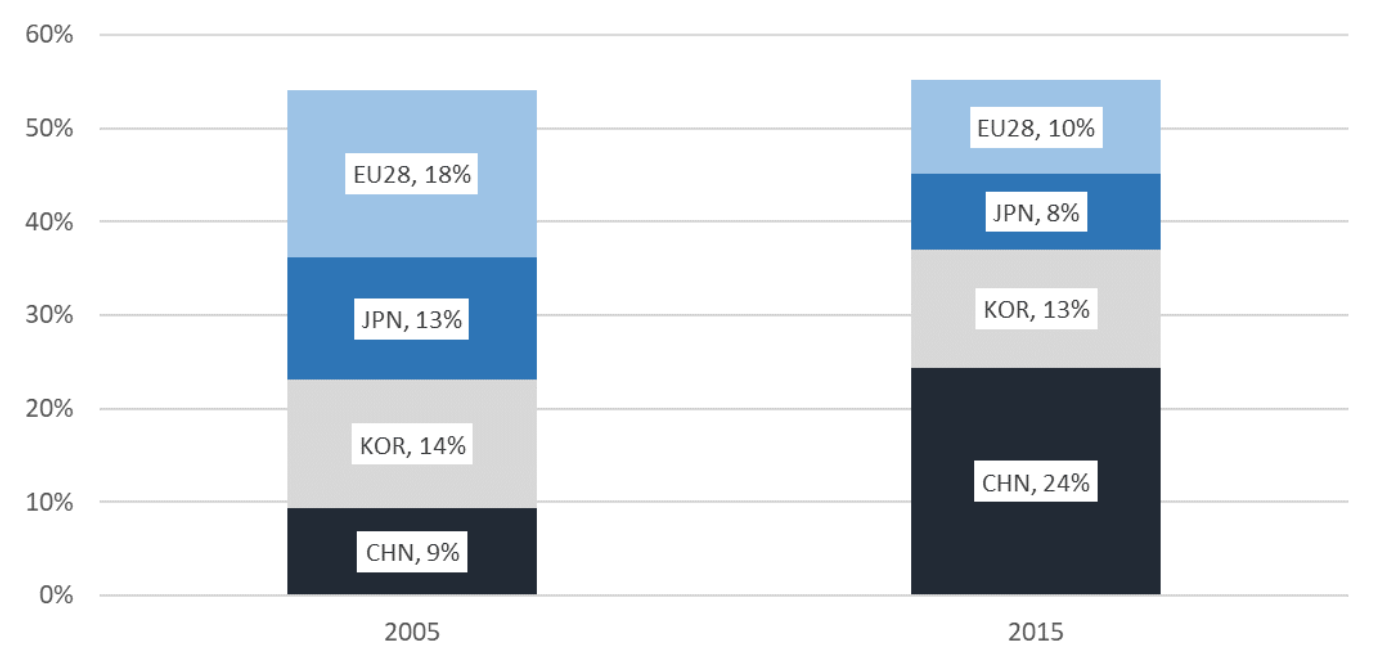

Note: For comparability, all current 28 EU member states are included in the number for 2005 and 2015. Source: OECD Trade in Value Added (2018).

Over the same period, Korea maintained its share of global value added of approximately $13 \%$, which is in line with the fact that Korea's share of global output value also remained relatively stable at around $16 \%$ in 2005 and 2015 (Figure 10), corresponding to a share in CGT of $33 \%$ in both years. ${ }^{26}$ On the other hand, Japan and the EU28 recorded a decline in their share of global value creation in shipbuilding, also in line with a decrease in share of production value in USD, as illustrated in Figure 10 (14\% to 9\% in Japan, 22\% to $12 \%$ in the EU28) and deliveries in CGT (28\% to $18 \%$ in Japan, $12 \%$ to $4 \%$ in the EU28). Finally, the value added share of the USA decreased from $21 \%$ in 2005 to $16 \%$ in 2015 , while its output share declined from $13 \%$ to $10 \%$. These values may primarily be a result of the country's naval production as mentioned previously, which is part of the industry category for this analysis (see Annex A for a description of the industry code). However, this fact makes the country's shares hardly comparable with those of other analysed shipbuilding economies and are therefore excluded from the graph. 
Figure 10. Domestic output as share of global output value, shipbuilding industry

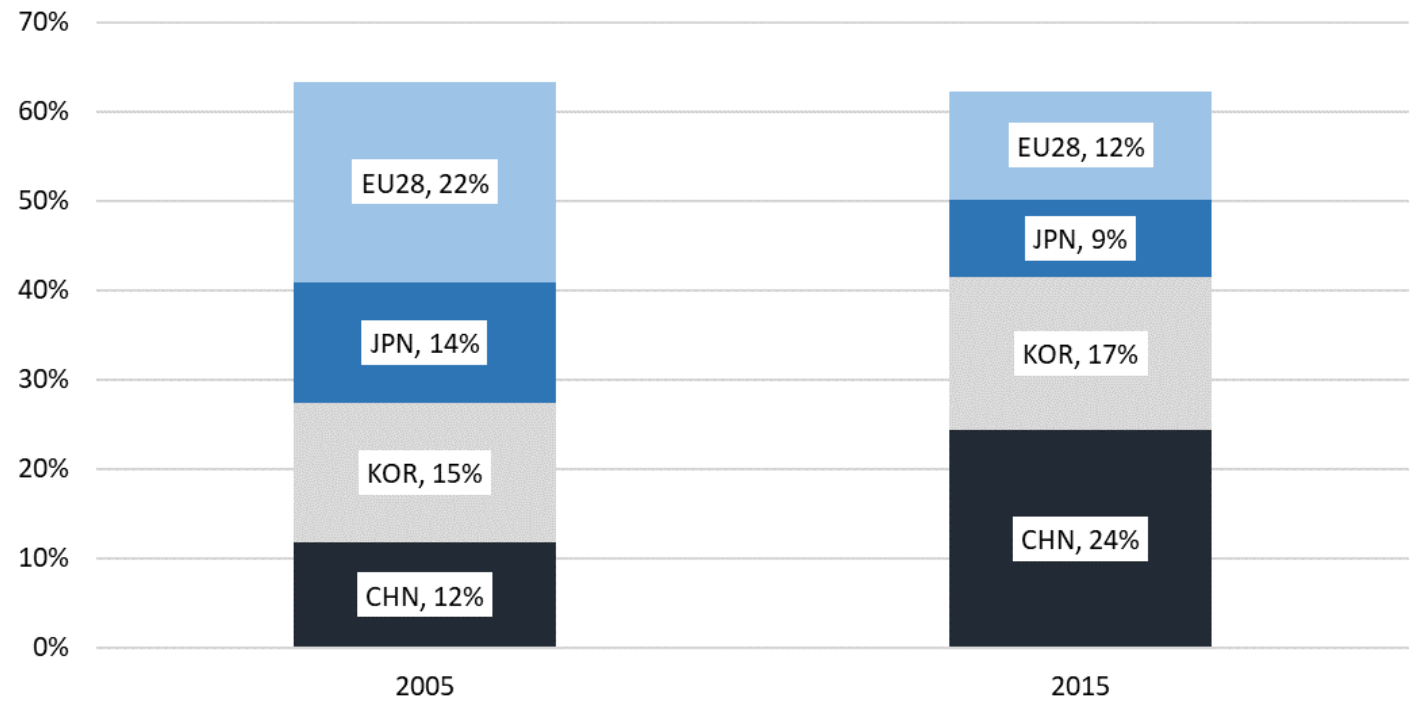

Note: For comparability, all current 28 EU member states are included in the number for 2005 and 2015. Source: OECD Trade in Value Added (2018).

\subsection{A Focus on Intermediate Inputs}

While the preceding results focused on the value added generation of the shipbuilding industry, the following analysis provides more insights into the cost structure of intermediate inputs to ship assembly across economies. Figure 11 shows the results of intermediate input costs as shares of total ship production value for 2015. Despite the difference in shares across the four economies, the top five supplier industries consistently are iron and steel (ISIC 241), shipbuilding itself (ISIC 301), wholesale $\operatorname{trade}^{27}$ (ISIC 46), machinery and equipment (ISIC 28) as well as fabricated metal products (ISIC 25).

The shares of iron and steel costs are relatively similar for the three major shipbuilding economies, making up between $7 \%$ and $10 \%$ (China 10\%, Korea $7 \%$ and Japan $10 \%$ ) of total ship production value. In contrast, this share is relatively low for the EU28 with only $3 \%$. Possible reasons for these differences in cost shares will be outlined below by relating the results to the economies' product mix.

The cost share of intra-shipbuilding transactions ranges between $7 \%$ for China and $14 \%$ for Japan with Korea (9\%) and the EU28 (12\%) in the middle. Intra-sector transactions in the shipbuilding industry can be a result of outsourcing activities to other ship yards (e.g. production of vessel hulls), or yard collaboration for the construction of offshore platforms or warships (e.g. companies specialised in naval construction source certain inputs from commercial shipbuilders and vice versa). Such cases might not be unusual, as recent examples may indicate. Japan's Mitsui E\&S Shipbuilding decided to contract commercial shipbuilding to partner Tsuneishi Shipbuilding, while another part of the shipyard will focus on producing naval vessels (Nikkei Asian Review, 2018 [26]), which could result in intra-industry transactions. 
Figure 11. Disaggregation of total output into value added and costs of intermediate inputs for 2015

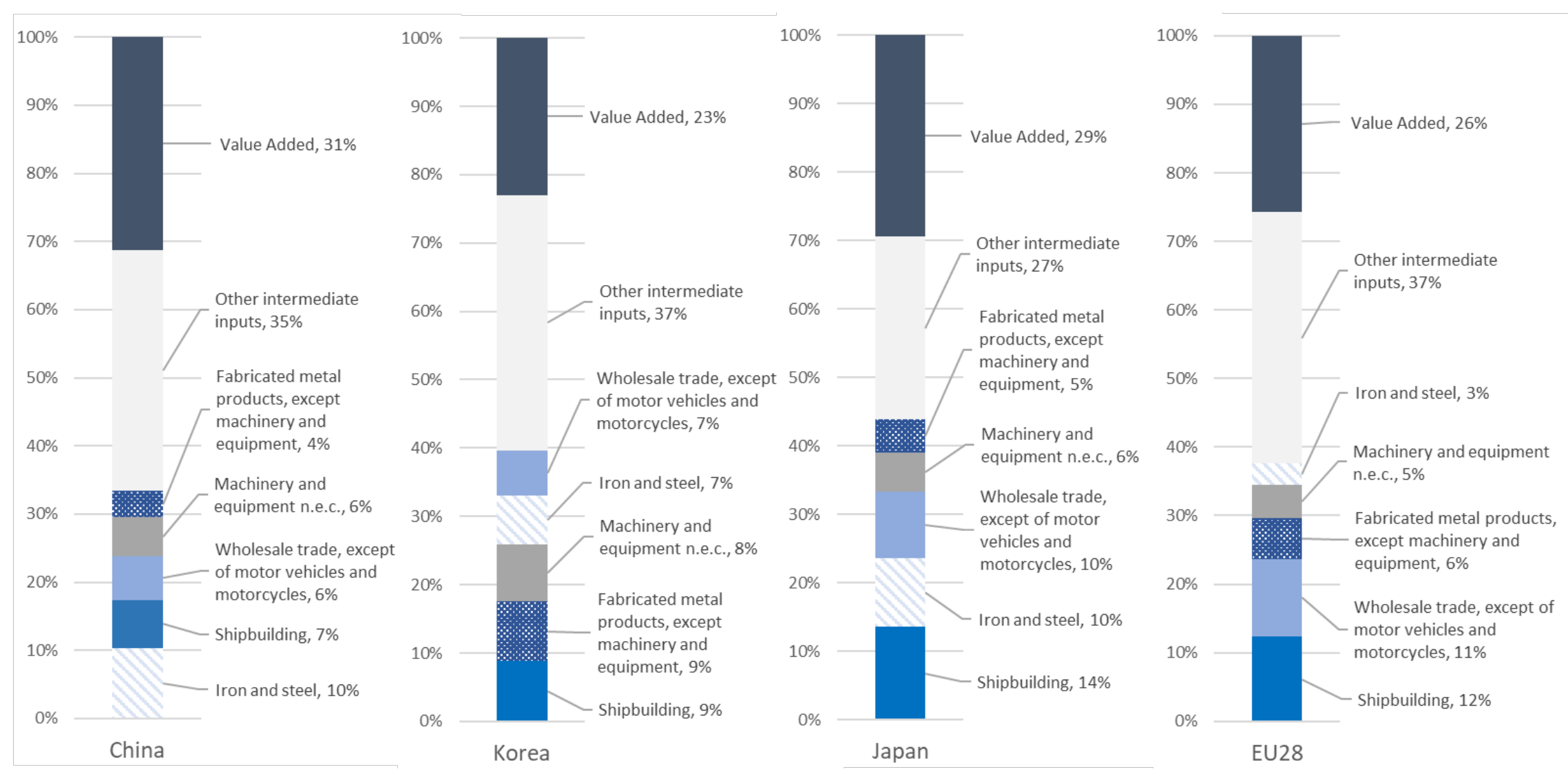

Note: n.e.c. stands for "not elsewhere classified", only the five biggest intermediate inputs are disaggregated, which are calculated in basic prices. Shares might not add up to $100 \%$ because of rounding.

Source: OECD Trade in Value Added (2018). 
Wholesale trade comprises a variety of different products, including among others the wholesale of machinery, equipment and supplies such as computers, telecommunications equipment, specialised machinery for all kinds of industries and general-purpose machinery (United Nations, 2008 ${ }_{[27]}$ ). The share across economies ranges from $6 \%$ for China to $11 \%$ for the EU28 with Korea (7\%) and Japan (10\%) between the two.

Machinery and equipment includes, among others, the manufacture of general-purpose and special-purpose machinery, such as engines and turbines (except for aircraft, vehicle and cycle engines), marine engines, hydraulic components, lifting and handling equipment (United Nations, 2008 $8_{[27]}$ ) used for ship production. The share is similar across economies with 6\% for China and Japan, 8\% for Korea, and 5\% for the EU28.

The category "fabricated metal products" (except machinery and equipment discussed above) contains, among others, the manufacture of metal products such as metal frameworks or parts for construction, as well as metal container-type objects such as reservoirs, tanks and central heating boilers, and steam generators (United Nations, $\left.2008_{[27]}\right)$. The shares are relatively similar for China (4\%), Japan (5\%) and the EU28 (6\%), with a slightly higher result for Korea ( $9 \%)$.

The results provide a first overview of the shares of intermediate input costs across economies. Yet, it is important to highlight that a direct comparison is not possible and the results shall be viewed with caution. For instance, as outlined in Figure 12, the cost shares of inputs into shipbuilding vary between ship types. While bulkers, containerships and oil tankers require comparatively more steel components and propulsion \& power generation parts as inputs, LNG and offshore vessels need more cargo handling equipment (Brun and Frederick, 2017 $\left.{ }_{[9]}\right)$.

These variations in cost shares across ship types might partly explain the differences in cost shares and input costs across economies as discussed earlier in relation to Figure 11, in particular in view of the diversity of the four shipbuilding economies' product mix. In 2015, the year considered in Figure 11, China's ship production consisted mainly of the two ship types bulkers and tankers, which made up $48 \%$ and $10 \%$ of the country's deliveries in terms of CGT, respectively. ${ }^{28}$ As presented in Figure 12, these two ship categories stand out with their steel input required for production. This in turn might be one reason why the iron and steel input costs account for a slightly larger share (10\%) of China's intermediate input costs for ship production compared to other economies, especially the EU28 and Korea.

In the case of Korea, gas carriers accounted for a substantial part of deliveries in terms of CGT in 2015 (24\%), after containerships (31\%) and tankers (28\%). ${ }^{29}$ As depicted in Figure 12, steel makes up a much smaller portion of the material and equipment costs of LNG carriers compared to bulkers, possibly being one reason for the relatively lower share of iron and steel of total ship costs in Korean shipbuilding. Furthermore, the category "fabricated metal products (except machinery and equipment)" features more prominently in Korea than in the other analysed economies. As this category includes items such as reservoirs and tanks, the Korean focus on gas carriers might explain part of this difference given the need for such inputs for the production of this ship category. There is evidence, however, that subcontracting is increasingly widespread in the Korean shipbuilding industry in an effort to reduce labour costs (Hassink and Shin, $\left.2005_{[28]}\right),{ }^{30}$ which could imply that any of these costs might enter the statistic not under the direct input category but through other categories related to subcontracting activities.

The focus of EU28 shipbuilders on high-value vessels, such as cruise ships, arctic vessels etc. could also help explain their cost structure. The cost share of steel, for instance, is 
significantly lower than in other jurisdictions, possibly because of the higher overall costs, reducing the cost share of steel products relative to the other high value inputs for this ship type. The high value of components in cruise ships, for instance related to tourism activities on deck, might also explain the relatively higher share of wholesale trade products depicted in Figure 11.

Figure 12. Cost shares of materials and equipment/systems by ship types

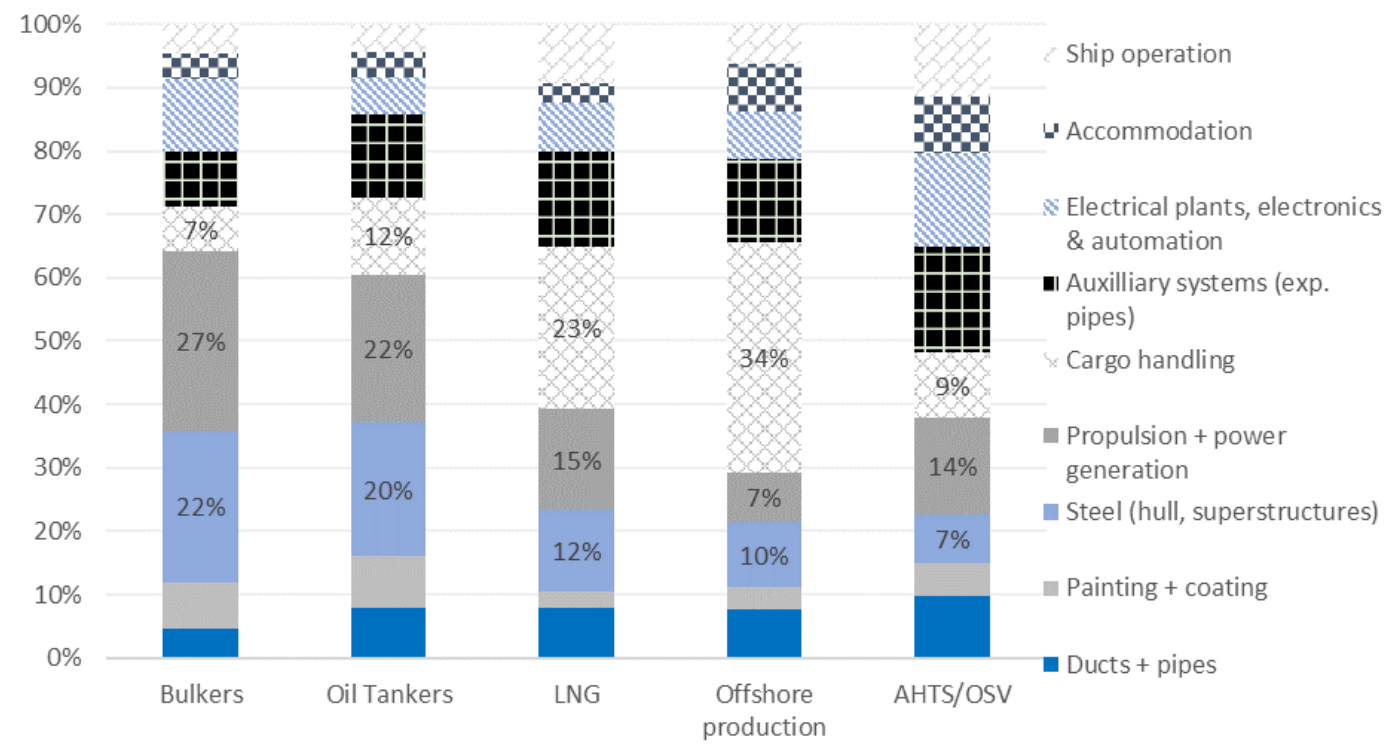

Note: The graph has been reproduced from Brun and Frederick $\left(2017_{[9]}\right)$. The authors of the report calculated the shares from (European Commission, 2014 ${ }_{[29]}$ ) which is based on purchase forecasts for 2013-17. The "materials" category consists of steel, painting/coating, and pipes + ducts. The "equipment/systems" category consists of all other physical input categories.

"AHTS" stands for Anchor Handling Tug Supply vessels, and "OSV" for Offshore Support Vessel

Source: Authors' representation based on Brun and Frederick (2017[9])

Supplier networks and negotiated contract-prices will furthermore influence the cost shares across firms and economies. Owing to data limitations, an analysis at such a disaggregated data level was not possible, however. Besides, ship production usually takes several years depending on demand for newbuilt vessels and ship yard capacity. In combination with different production cycles across economies (related to differences in the timing of purchase of various inputs) the cost structure can vary.

Finally, it is worth noting that the different results across jurisdictions can also be influenced by national accounting standards despite the international efforts made to standardise industrial classification tables (United Nations, 2008 [27]). For instance, the cost share of "shipbuilding" in Japan is higher than in other economies possibly also because of the fact that Japanese statistics include "internal combustion engines for vessels" as a subcategory of "shipbuilding". In other economies, these ship engines might potentially be classified under "machinery", for instance. A similar case applies for Korea, where "ship repair and ship parts" are included in the classification "shipbuilding". These and similar caveats presumably also have to be taken into account when looking at other sectors and other economies, meaning that a direct comparison of cost shares should be undertaken with caution. 


\subsection{Sourcing Patterns of Main Shipbuilding Economies}

After a general overview and comparison between the four major shipbuilding economies in the previous section, this part takes a closer look at those economies' sourcing patterns. Among the four jurisdictions studied for this purpose, China appears to be the most selfsufficient and inward focused in its sourcing activity, which is also reflected in its high share of domestic value added discussed above ( $89 \%$ in 2015). Korea, in contrast, seems to be more globally integrated and features more strongly as a user of foreign intermediate inputs, which is also mirrored in its lower share of domestic value added content $(65 \%$ in 2015). ${ }^{31}$ With a share of less than $10 \%$ of the total output, foreign inputs are also comparatively low in Japan and the EU28 when compared to Korea, but still higher than in the case of China. Figure 13 provides a comparison of the shares of domestically ${ }^{32}$ sourced intermediates for the five main inputs to shipbuilding that were detailed in Figure 11 and are the same for all four studied economies.

Figure 13. Domestically sourced share of five major intermediate inputs

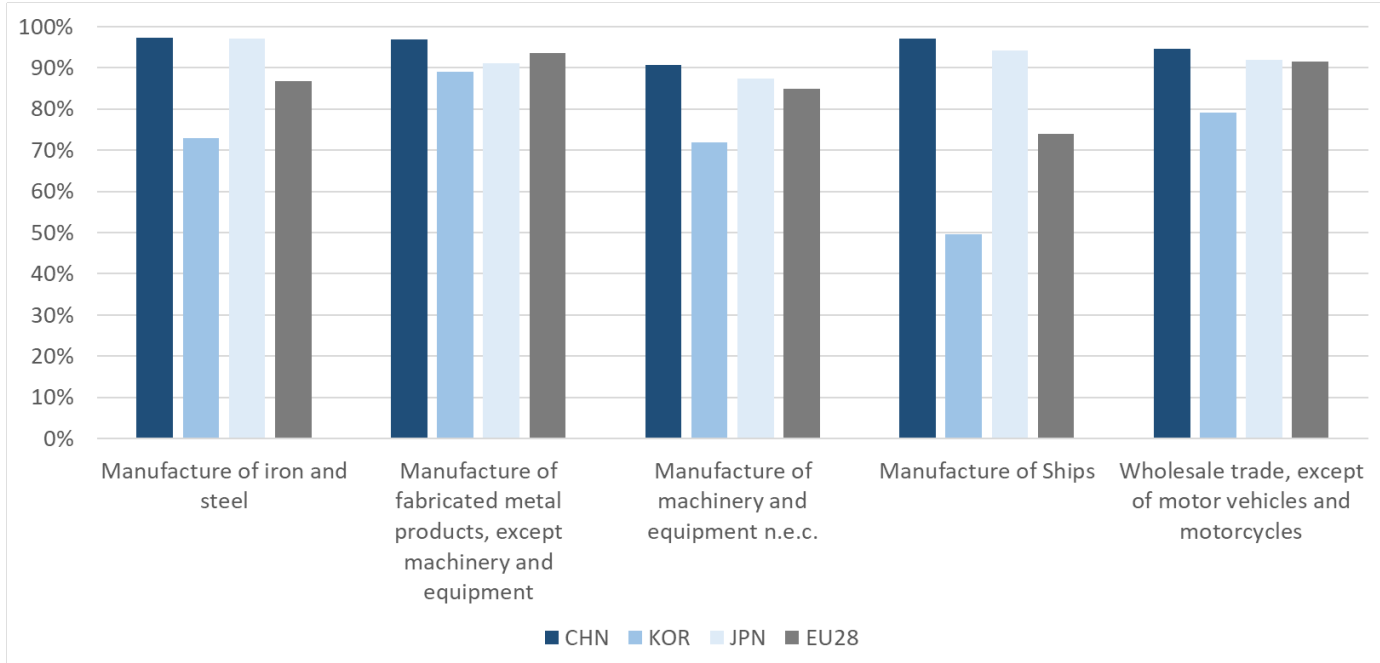

Note: Values relate to the year 2015.

Source: OECD Trade in Value Added (2018).

Beginning with the currently biggest ship producer, ${ }^{33}$ China sourced more than $90 \%$ of its inputs for ship production domestically in 2015 - the highest share amongst its peers. This value does not only pertain for the major inputs detailed in Figure 13, but also applies to a broad range of intermediates, resulting in the total share of foreign intermediate inputs in terms of total output value not exceeding 4\% (see also Figure 14). Among the five inputs studied, China's foreign share of machinery and equipment seems to be highest with around $10 \%$ (although this share is still relatively low compared to the other jurisdictions studied). Under its "Made in China 2025" initiative, the country aims to further increase, among others, its domestic share of high-tech ship components (MERICS, 2016 [25]) and its global market share of maritime equipment (US Chamber of Commerce, $2017_{[30]}$ ). Further studies on this topic could analyse in more detail whether and to what extent Chinese policies aiming for more domestic value added content could explain this high share of domestic sourcing behaviour - also in comparison to its peers. 
In contrast to China's high share of domestically sourced intermediates, Korea's considerably lower corresponding values are quite noteworthy. ${ }^{34}$ Particularly striking is the fact that approximately half of intra-shipbuilding transactions are sourced from abroad, which is in line with Korea's general tendency to sub-contract a large part of its shipbuilding activity as discussed above. In addition, the country sources more than onefourth of machinery and equipment from foreign suppliers, implying that the domestic supplier network for marine equipment is not sufficient to meet domestic demand. More detailed results reveal that Korea sources this foreign share mainly from the EU28, China and Japan. This is in line with the fact that particularly Europe has a strong position in marine equipment worldwide and acts as a net exporter (Ecorys, 2009[31]). Besides, with more than $25 \%$ compared to less than $5 \%$ in both China and Japan, Korea sources a relatively high share of iron and steel from abroad, despite being the world's $6^{\text {th }}$ largest steel producer in 2015 (World Steel Association, 2016 [32]). There is anecdotal evidence that, faced with low profits, major Korean ship producers such as Hyundai Heavy Industries and Samsung Heavy Industries considered increasing their steel imports from China, which reportedly were cheaper than Korean domestic supplies (SEAISI, 2012[33]). ${ }^{35}$ This may partly explain the larger share of foreign steel input in the case of Korea.

In Japan, iron and steel is sourced to around 97\% domestically, a share just as high as in China. The reason for this high value in the case of Japan might partly be due to the long term relationships that certain Japanese shipbuilders have established with domestic steel producers in order to ensure a stable supply of high quality steel. A further explanation could be that new ship specific steel has been developed in cooperation with steel mills, making these relationships strategically important. ${ }^{36}$ Furthermore, Japan's results show that the highest share of foreign sourced intermediates is found in the category of machinery and equipment. Further analysis shows that Japan likely sources those inputs from China and Europe. Nevertheless, according to exchanges with the Shipbuilders' Association of Japan (SAJ) there are instances where certain engines are produced in Japan under licencing from European companies.

A closer look at the supplier economies for ship production shows that the major four shipbuilding economies basically seem to be sourcing their foreign intermediate inputs from each other (Figure 14). While China relies heavily on domestic suppliers (only $\sim 4 \%$ of final production value is sourced from abroad), the country is also interlinked with the EU28, Japan, Korea and the USA. Korea's major trading partners with respect to intermediate inputs used for ship production are China, followed by Japan, the EU28 and the USA. Japan predominantly sources its foreign inputs from China and to a lesser extent from the EU28, the USA and Korea. Finally, the EU28 has exposure in sourcing activity for ship construction with Korea, China and the USA. The USA thus appears as a major supplier for all four jurisdictions.

Overall, the results highlight the interconnectedness of ship production across economies in general, and across major shipbuilding economies in particular. It is therefore important to understand that government measures applied to a domestic industry may affect the activity and functioning of industries in major supplier countries, and potentially even in third countries. 
Figure 14. Major trading partners for intermediate inputs

Share of intermediate inputs originating from foreign economies as percentage of total output value

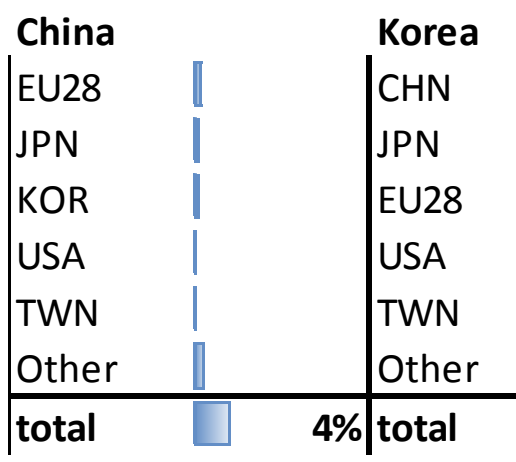

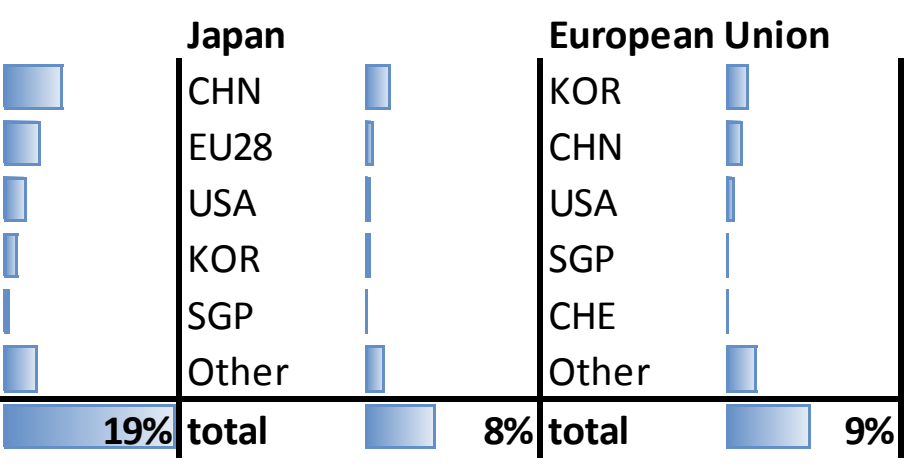

Note: Values relate to the year 2015.

Source: OECD Trade in Value Added (2018). 


\section{Concluding Remarks}

The emergence of Global Value Chains (GVCs) during the last few decades has also moved the shipbuilding industry towards an interconnected production approach. Intermediate goods are to some degree sourced from foreign economies, locally assembled into a final vessel and exported to other economies. Based on a unique Inter-Country Input-Output (ICIO) dataset broken down to the level of the shipbuilding industry, this paper provides new descriptive evidence about value generation and sourcing patterns in the shipbuilding industry across jurisdictions and time. While this study provides an initial description of the position of economies' shipbuilding industries in the global market, the next step would be to understand which factors drive domestic value generation, differences in sourcing patterns and costs.

While the report does not explicitly discuss policy implications of the international fragmentation of the shipbuilding sector, it does bring to the fore how different policies across countries will have impacts on the structure of GVCs, and highlights their impacts throughout the economy and across countries. In particular, in view of the interconnected production networks associated with shipbuilding, the results underscore that government measures affecting a specific sector in one country can have implications for upstream or downstream sectors of other economies.

Localisation-based policies are a case in point as highlighted in a recent OECD report on Local Content Requirements in the shipbuilding industry (Gourdon and Guilhoto, 2019[34]). Similarly, trade policy actions against third countries could eventually affect the country implementing the action, for instance, if domestically produced intermediate goods are exported and re-imported in the form of downstream products. It is through the lens of a data infrastructure such as Trade in Value Added (TiVA) that such indirect impacts can be understood. Therefore, the discussion about trade and industrial policy in the shipbuilding industry across countries needs to take a value chain perspective. 


\section{Annex A. Description of Industry Classification of Shipbuilding}

The analysis is based on the industry classification codes 3011 "Building of Ships and Floating Structures" and 3012 "Building of Pleasure and Sporting Boats" of the International Standard Industrial Classification of All Economic Activities (ISIC), Rev. 4 (United Nations, 2008 [27]):

3011 - Building of ships and floating structures: This class includes the building of ships, except vessels for sports or recreation, and the construction of floating structures. The following items are included:

- building of commercial vessels:

○ passenger vessels, ferry boats, cargo ships, tankers, tugs etc.

- building of warships

- building of fishing boats and fish-processing factory vessels

- building of hovercraft (except recreation-type hovercraft)

- construction of drilling platforms, floating or submersible

- construction of floating structures:

- floating docks, pontoons, coffer-dams, floating landing stages, buoys, floating tanks, barges, lighters, floating cranes, non-recreational inflatable rafts etc.

- manufacture of sections for ships and floating structures

3011 - Building of pleasure and sporting boats: This class includes:

- manufacture of inflatable boats and rafts

- building of sailboats with or without auxiliary motor

- building of motor boats

- building of recreation-type hovercraft

- manufacture of personal watercraft

- manufacture of other pleasure and sporting boats:

○ canoes, kayaks, rowing boats, skiffs 


\begin{abstract}
Notes
${ }^{1}$ Throughout the report, we use the terms "supply chain" and "value chain" interchangeably.

${ }^{2}$ Further studies dealing with the effect of GVC on productivity are, among others, Baldwin and Yan $\left(2014_{[36]}\right)$ on the Canadian manufacturing sector; Bas and Strauss-Kahn, $\left(2013_{[45]}\right)$ or Caliendo and Rossi-Hansberg (2012[37]).

${ }^{3}$ See also Marcolin, Miroudot and Squicciarini $\left(2016_{[43]}\right)$.

${ }^{4}$ The industry with the highest value in that regard is coke, petroleum with almost $300 \%$ followed by chemicals $(\sim 150 \%)$, motor vehicles $(\sim 140 \%)$ and basic metals $(\sim 135 \%)$.

${ }^{5}$ Examples include the consequences of a lightning strike on cell phone production (Sheffi, 2007[38]) or the repercussions of the 2011 earthquake in Japan on the global auto industry (Gereffi and Luo, $\left.2014_{[11]}\right)$; Sheffi and Rice $\left(2005_{[40]}\right)$ describe the impact of the closure of US borders for incoming and outgoing flights due to the September 11, 2001 terrorist attacks on the global auto industry.
\end{abstract}

${ }^{6}$ For instance, the Norwegian shipbuilding industry increasingly outsources the hull production or other steel work to countries with lower factor costs to be able to "focus on the more advanced outfitting tasks, such as the installation and commissioning of machinery and deck equipment, electrical systems, and accommodation" (Semini et al., 2018[39]).

${ }^{7}$ Workers performing manual or cognitive tasks that can rather easily be automated are most likely to be affected by GVCs since many of these functions can be offshored (OECD, 2013 $\left.{ }_{[1]}\right)$. OECD $\left(2013_{[1]}\right)$ work estimates that "at least $10 \%$ of the decline of the share of labour in national income is due to increasing globalisation, and in particular to pressure from the relocation of parts of GVCs and from import competition from companies that produce in countries with low labour costs"

${ }^{8}$ Value added is measured as the sum of employee compensation, operating surplus, depreciation of fixed capital and other net taxes on production (less subsidies).

${ }^{9}$ As a comparison, the share of value added over final output for the industry classification "Motor vehicles, trailers and semi-trailers" (which includes automobiles) in 2015 was around 25\%.

${ }^{10}$ For more details on GVCs please see OECD $\left(2013_{[1]}\right)$, upon which most of this section is based.

${ }^{11}$ For early work on this see for instance Gary Gereffi $\left(1994_{[44]}\right)$, who introduced the concept of the "global commodity chain".

${ }^{12}$ For more information, an explanatory note describes these linkages as follows: "Backward GVC participation refers to the ratio of the "Foreign value added content of exports" to the economy's total gross exports. This is the "Buyer" perspective or sourcing side in GVCs, where an economy imports intermediates to produce its exports. Forward GVC participation corresponds to the ratio of the "Domestic value added sent to third economies" to the economy's total gross exports. It captures the domestic value added contained in inputs sent to third economies for further processing and export through value chains. This is the "Seller" perspective or supply side in GVC participation." (OECD-WTO, 2018[35]).

${ }^{13}$ For more information on the database please visit: http://oe.cd/tiva.

${ }^{14}$ GVC participation also dropped significantly in 2009, but then increased again in 2010 and 2011. The ECB estimate approximates GVC participation by the share of intermediate goods in total goods imports for recent years as input-output tables were not yet available.

${ }^{15}$ While the authors have not found proof that robotics lead to reshoring (sometimes also called back-shoring or on-shoring) of production, this lack of evidence might be due to the quite recent increase in the use of robotics.

${ }^{16}$ CGT data in this report, absolute or relative, are based on Clarkson World Fleet Register. 
${ }^{17}$ With new environmental regulations entering into force, the complexity of ships and thus the shipbuilding value chain is likely to increase even further in the future.

18 i.e. standardised vessels, such as containerships, bulkers, tankers or specialised vessels, such as LNG/LPG carriers, cruise ships etc.

19 These results are in line with the earlier studies finding that " $50-70 \%$ of the value added comes from external subcontractors and suppliers, whereas for more complex ships this can be as high as $70-80 \% "$ (results by IKEI $\left(2009_{[47]}\right)$, as described in Ecorys $\left(2009_{[31]}\right)$ ). The study by Ecorys does not, however, discuss a country comparison and the ratios refer to 2009.

${ }^{20}$ See Annex A for more details on the industry classification used in the analysis.

${ }^{21}$ The impact of this policy on the US economy is analysed in more detail in Gourdon and Guilhoto $\left(2019_{[34]}\right)$.

${ }^{22}$ All transactions between EU28 countries are treated as domestic for this comparison.

${ }^{23}$ In order to improve comparability of results, this calculation treats Bulgaria, Rumania and Croatia as EU members in 2005 although they joined thereafter.

${ }^{24}$ It should be noted, however, that comparisons to CGT values in this section are only illustrative, as they are taken from a different data source, namely Clarkson World Fleet Register.

${ }^{25}$ Further reasons that could explain the increase in the share of domestic value added of China might be related to an increase in value added factors, such as salaries, profits (for instance due to quality improvements of vessels) or taxes.

${ }^{26}$ It has to be noted, however, that Korea's share varied between these dates.

27 "Wholesale is the resale (sale without transformation) of new and used goods to retailers, to industrial, commercial, institutional or professional users, or to other wholesalers, or involves acting as an agent or broker in buying goods for, or selling goods to, such persons or companies" (United Nations, 2008 [27]).

${ }^{28}$ Calculated from Clarkson World Fleet Register.

${ }^{29}$ Calculated from Clarkson World Fleet Register.

${ }^{30}$ In addition, Ecorys $\left(2009_{[31]}\right)$ describes the case of subcontracting in Korean shipbuilding on the example of Samsung. In 2003, the company had sub-contractors that either contributed directly from the shipyard or were located elsewhere. The total workforce of all of these firms together was able to produce approximately two-thirds of Samsung's overall shipbuilding output.

${ }^{31}$ For the figures referred to see Figure 8 in the previous section.

32 Intra-EU transactions are again treated as domestic transactions in this calculation.

${ }^{33}$ In 2018, China was the largest ship producer in terms of CGT, followed by Korea and Japan, according to data from Clarkson World Fleet Register.

34 At the same time, as noted previously, this lower share of domestic sourcing might not be surprising to some extent given the smaller size of the Korean economy.

35 This finding stands in contrast to earlier anecdotal evidence that Hyundai sourced $90 \%$ of its steel demand from the Korean company POSCO, as quoted in Eich-Born (2005, p. 114 [46]).

36 This information is based on exchanges between the Secretariat and the Shipbuilder's Association of Japan. It is further supported by an article by Suzuki et al. $\left(2004_{[41]}\right)$, which describes several steel products that JFE has to offer specifically for the shipbuilding industry, as well as examples of steel products that Nippon Steel developed in cooperation with Imabari Shipbuilding and Mitsubishi Heavy Industry (Hayakawa, 2010[42]). 


\section{References}

Baldwin, J. and B. Yan (2014), Global value chains and the productivity of Canadian manufacturing firms, Statistics Canada.

Baldwin, R. (2012), "Global Supply Chains: Why They Emerged, Why They Matter, and Where They Are Going”, Fung Global Institute Working Paper FGI-2012-1, https://pdfs.semanticscholar.org/a060/496c28496be89dee84d64eea98370afa814d.pdf (accessed on 4 April 2018).

Bas, M. and V. Strauss-Kahn (2013), "Input-Trade Liberalization, Export Prices and Quality Upgrading”, Sciences Po Economics Discussion Papers 2013-13.

Brodda, J. (2014), The Shipbuilding and Offshore Marine Supplies Industries, http://www.oecd.org/sti/ind/oecd-shipbuilding-workshop-brodda.pdf.

Brun, L. and S. Frederick (2017), Korea and the Shipbuilding Global Value Chain, https://gvcc.duke.edu/wpcontent/uploads/Duke KIET_Korea and the Shipbuilding_GVC_CH_4.pdf (accessed on 30 October 2018).

Caliendo, L. and E. Rossi-Hansberg (2012), "The impact of trade on organization and productivity", Quarterly Journal of Economics, Vol. 127/3, pp. 1393-1467, http://dx.doi.org/10.1093/qje/qjs016.

Constantinescu, C., A. Mattoo and M. Ruta (2017), Does Vertical Specialization Increase Productivity?, World Bank Group, https://openknowledge.worldbank.org/handle/10986/26145.

Criscuolo, C. and J. Timmis (2017), “The Relationship Between Global Value Chains and Productivity", International Productivity Monitor, Vol. 32, pp. 61-83.

De Backer, K. et al. (2018), "Industrial robotics and the global organisation of production", OECD Science, Technology and Industry Working Papers, No. 2018/03, OECD Publishing, Paris, http://dx.doi.org/10.1787/dd98ff58-en.

De Backer, K. and S. Miroudot (2013), Mapping Global Value Chains, OECD Publishing, Paris, https://doi.org/10.1787/5k3v1 trgnbr4-en.

ECB (2016), Understanding the weakness in global trade - What is the new normal?, https://www.ecb.europa.eu/pub/pdf/scpops/ecbop178.en.pdf (accessed on 5 April 2018).

Ecorys (2009), Study on Competitiveness of the European Shipbuilding Industry, https://ec.europa.eu/docsroom/documents/10506/attachments/1/translations/en/renditions/nati ve.

Eich-Born, M. (2005), Transformation der ostdeutschen Schiffbauindustrie: Anpassungsprozesse in einem global-lokalen Institutionengefüge, Münster : LIT. 
Elms, D. and P. Low (eds.) (2013), Global value chains in a changing world, World Trade Organisation Publishing, https://www.wto.org/english/res_e/booksp_e/aid4tradeglobalvalue13 e.pdf (accessed on 17 October 2018).

European Commission (2014), Study on Competitive Position and Future Opportunities for the European Marine Supplies Industry, https://publications.europa.eu/en/publication-detail//publication/df9d2276-cb29-4c6d-84a7-e454922e8297.

Gereffi, G. (1994), The organization of buyer-driven global commodity chains: how US retailers shape overseas production networks, in G. Gereffi and M. Korzeniewicz (eds), "Commodity Chains and Global Capitalism", Westport, CT: Praeger, pp. 95-122.

Gereffi, G. and X. Luo (2014), Risks and Opportunities of Participation in Global Value Chains, http://documents.worldbank.org/curated/en/914141468325443509/pdf/WPS6847.pdf (accessed on 17 October 2018).

Gourdon, K. and J. Guilhoto (2019), "Local Content Requirements and their Economic Effect on Shipbuilding - A Quantitative Assessment", OECD Science, Technology and Industry Policy Papers, OECD Publishing, Paris, https://doi.org/10.1787/90316781-en.

Hassink, R. and D. Shin (2005), "South Korea's shipbuilding industry: From a couple of Cathedrals in the desert to an innovative cluster", Asian Journal of Technology Innovation, Vol. 13/2, pp. 133-155, http://dx.doi.org/10.1080/19761597.2005.9668611.

Hayakawa, K. (2010), Steel for shipbuilding in Japan, http://news.nost.jp/2010/03/steel-forshipbuilding-in-japan/ (accessed on 3 November 2018).

IKEI (2009), Comprehensive sectoral analysis of emerging competencies and economic activities in the European Union: building and repairing of ships and boats sector, Office for Official Publications of the European Communities.

Kowalski, P. et al. (2015), "Participation of Developing Countries in Global Value Chains Implications for Trade and Trade-Related Policies", OECD Trade Policy Papers, No. 179, OECD Publishing, Paris, https://doi.org/10.1787/5js33lfw0xxn-en.

Kummritz, V. (2016), “Do global value chains cause industrial development?”, CTEI Working Paper No. 2016-01, https://repository.graduateinstitute.ch/record/293917/files/CTEI-201601.pdf.

Lopez Gonzalez, J. (2016), "Using Foreign Factors to Enhance Domestic Export Performance: A Focus on Southeast Asia", OECD Trade Policy Papers, No. 191, OECD Publishing, Paris, http://dx.doi.org/10.1787/5jlpq82v1jxw-en.

Marcolin, L., S. Miroudot and M. Squicciarini (2016), "GVCs, Jobs And Routine Content Of Occupations", OECD Trade Policy Papers, No. 187, OECD Publishing, Paris, http://dx.doi.org/10.1787/5jm0mq7kr6s8-en.

McKinsey (2014), Global flows in a digital age: How trade, finance, people, and data connect the world economy, McKinsey Global Institute, https://www.mckinsey.com/ /media/McKinsey/Global\%20Themes/Globalization/Global\%20 flows $\% 20 \mathrm{in} \% 20 \mathrm{a} \% 20$ digital $\% 20 \mathrm{age} / \mathrm{Global}$ flows in a digital age Full report\%20March 2015.ashx (accessed on 6 April 2017).

MERICS (2016), Made in China 2025 - The making of a high-tech superpower and consequences for industrial countries, https://www.merics.org/sites/default/files/201807/MPOC No.2 MadeinChina2025 web.pdf (accessed on 29 August 2018). 
Nikkei Asian Review (2018), Mitsui's main shipyard quits commercial vessels,

https:/asia.nikkei.com/Business/Companies/Mitsui-s-main-shipyard-quits-commercialvessels (accessed on 3 November 2018).

OECD (2018), Development of the OECD Inter-Country Input-Output Database 2018 Edition.

OECD (2018), The changing nature of international production: Insights from Trade in Value Added and related indicators, https://www.oecd.org/industry/ind/tiva-2018-flyer.pdf (accessed on 25 September 2019).

OECD (2015), Global value chains and trade in value-added: an initial assessment of the impact on jobs and productivity, OECD Publishing, Paris, https://doi.org/10.1787/5jlvc7sb5s8w-en.

OECD (2013), Interconnected Economies: Benefiting from Global Value Chains, OECD Publishing, Paris, https://doi.org/10.1787/9789264189560-en.

OECD-WTO (2018), Trade in Value-Added and Global Value Chains profiles - An explanatory note, https://www.wto.org/english/res e/statis e/miwi e/Explanatory_Notes e.pdf (accessed on 28 March 2018).

SEA Europe (2017), Presentation made at the WP6 meeting on 21 November 2017.

SEAISI (2012), South Korean shipbuilding companies to buy more steel plate from China, http://www.seaisi.org/News/2109/South+Korean+shipbuilding+companies+to+buy+more+ste el+plate+from+China (accessed on 3 November 2018).

Semini, M. et al. (2018), "Offshoring Strategies in Norwegian Ship Production", Journal of Ship Production and Design, Vol. 34/1, pp. 59-71, https://doi.org/10.5957/JSPD.160035.

Sheffi, Y. (2007), Building a Resilient Organization, National Academy of Engineering of the National Academies, pp. 30-36, https://www.nae.edu/File.aspx?id=7405\&v=70df971.

Sheffi, Y. and J. Rice (2005), A Supply Chain View of the Resilient Enterprise, MIT Sloan Management Review, https://www.researchgate.net/publication/255599289 A Supply Chain View of the Resilie nt_Enterprise (accessed on 17 October 2018).

Stopford, M. (2003), Maritime Economics, Routledge, London and New York.

Sturgeon, T. (2013), Global Value Chains and Economic Globalization, http://ec.europa.eu/eurostat/documents/7828051/8076042/Sturgeon-report-Eurostat.pdf (accessed on 28 March 2018).

Suzuki, S. et al. (2004), "Steel Products for Shipbuilding", JFE Technical Report No.2, http://www.jfe-steel.co.jp/en/research/report/002/pdf/002-05.pdf.

Tsai, Y. (2011), "The shipbuilding industry in China", OECD Journal: General Papers, Vol. 2010/3, http://dx.doi.org/10.1787/gen papers-2010-5kg6z7tg5w51.

United Nations (2008), International Standard Industrial Classification of All Economic Activities (ISIC), Revision 4, https://www.bundesbank.de/resource/blob/612626/067f5294c6df434ea4528bdb62551f9b/mL/ isic-rev-4-data.pdf.

United States Maritime Administration (2013), The Economic Importance of the U.S. Shipbuilding and Repairing Industry, https://3snn221qaymolkgbj4a0vpey-wpengine.netdnassl.com/wp-content/uploads/2014/04/MARAD_Econ_Study_Final_Report 2013.pdf (accessed on 30 June 2019). 
US Chamber of Commerce (2017), Made in China 2025: Global Ambitions Built on Local Protections,

https://www.uschamber.com/sites/default/files/final made in china 2025 report full.pdf (accessed on 22 February 2019).

World Bank (2017), Measuring and analyzing the impact of GVCs on economic development, World Bank Group,

http://documents.worldbank.org/curated/en/440081499424129960/Measuring-and-analyzingthe-impact-of-GVCs-on-economic-development.

World Steel Association (2016), World Steel in Figures 2016,

https://www.worldsteel.org/en/dam/jcr:4f060d8b-3602-4ffe-9e87-

7e93e0659449/Word+Steel+in+-Figures+2016.pdf (accessed on 3 November 2018). 